\title{
Spatial Relationship between Floods and Poverty: The Case of Region of Dakar
}

\author{
Amy Cissé, Pierre Mendy* \\ Laboratory of Mathematics of the Decision and Numerical Analysis, Cheikh Anta Diop University, Dakar, Senegal \\ Email: *pierre.mendy@ucad.edu.sn
}

How to cite this paper: Cissé, A. and Mendy, P. (2018) Spatial Relationship between Floods and Poverty: The Case of Region of Dakar. Theoretical Economics Letters, 8, 256-281.

https://doi.org/10.4236/tel.2018.83019

Received: December 1, 2017

Accepted: February 6, 2018

Published: February 9, 2018

Copyright ( 2018 by authors and Scientific Research Publishing Inc. This work is licensed under the Creative Commons Attribution International License (CC BY 4.0).

http://creativecommons.org/licenses/by/4.0/ cc) (i) Open Access

\begin{abstract}
Since 2005 in Senegal, progress in reducing poverty has stagnated. Successive exogenous shocks and a slowdown in reforms have, in part, reduced average growth to $3.3 \%$, a rate barely above that of population growth (2.5\%). Exogenous shocks include floods, which have become recurrent in the country's major cities, but especially in the capital Dakar, where they remain an omnipresent reality. These floods, with heavy consequences sometimes even disastrous (damage and loss of human life), are one of the main reasons that push and/or keep poor households in a vicious circle of poverty. Indeed, thanks to the geographic information system implemented in this paper, the analysis of the spatial relationship between floods and poverty has made it possible to oppose the multidimensional and dimensional poverty rates of the department of Dakar, the least affected by floods, to those in Pikine, the most affected by the floods. It has also shown that the poorest populations in the region of Dakar are those affected by floods and are mainly located in the departments of Pikine, Guédiawaye and Rufisque. In Pikine, where floods were experienced in 2005, 2009 and 2011, multidimensional poverty rates crossed the $50 \%$ line while they are around $30 \%$ and $40 \%$ for Guédiawaye and $\mathrm{Ru}$ fisque respectively. Multidimensional poverty rates derive primarily from indicators such as nutrition, level of education, cooking fuel and holding of assets.
\end{abstract}

\section{Keywords}

Floods, Multidimensional Poverty, Dakar

\section{Introduction}

The main challenge of the millennium for development is the reduction of poverty in the world. For the developing countries in particular, this reduction of 
poverty remains a means of fighting hunger, mortality, disease and disasters. Senegal, like many sub-Saharan African countries, had therefore developed and implemented an economic and social policy document for growth and poverty reduction.

The latter, as a poverty reduction strategy document, achieved satisfactory results during the period 2003-2005 with economic growth which stood on a positive slope and an annual average of around 5\%: 6.7\% in 2003 after the slowdown in $2002,5.6 \%$ in 2004 and $5.5 \%$ in 2005 [1]. However, since 2005, progress in poverty reduction has stagnated. Successive exogenous shocks and slowing of reforms have, in part, resulted in an average growth rate of 3.3 percent, slightly higher than population growth ( 2.5 percent). Recent estimates, based on a 2011 household survey, showed that 46.7 percent of the Senegalese populations live in households with incomes below the national poverty cutoff [2].

Among the exogenous shocks suffered by Senegal, the floods have become a regular feature of the country's major cities, but especially in the capital Dakar, where they have remained a pervasive reality since 2005. Floods have the effect of keeping poor households in a vicious circle of poverty. The findings of the studies on the intergenerational impacts of shocks on household poverty in Senegal show that floods are among the main disasters that retain poor households in endemic poverty [3]. This is due to the fact that these households invest a large part of their resources in order to survive the shocks. Unfortunately, such strategies are neither sustainable nor effective. On the contrary, they only aggravate their vulnerability to future shocks. Moreover, poverty indicators (measured through the incidence, depth and severity of poverty) report poor performance in the peri-urban area of Dakar, which is often subject to flooding problems [4].

The region of Dakar, which is the most affected by the floods (in terms of the recurrence, the extent of the damage and losses), accounts for the largest number of poor people in absolute terms. The national agency for statistics and demography estimates its poor household rate at 26.1 percent for a population of 3 137196 inhabitants in 2013, nearly a quarter (23.2 percent) of the national population [5]. It is therefore legitimate to question a possible relationship between poverty and the floods noted in Dakar or whether poor people are more vulnerable to flooding. This paper presents an analysis of the multidimensional poverty suffered by the population of Dakar, particularly those exposed to floods. Indeed, we combine flood maps, representing the main flooded areas of Dakar in 2009 and 2011, with detailed data sets on health, education and the standard of living of individuals in order to detect a possible correlation between poverty levels and floods. And, unlike the studies that preceded it and for which poverty is measured by monetary indices, we focus on the multiple deprivations affecting the health, education and standard of living of the populations as well as on the geographical distribution of the poor population in Dakar. Thus, this work is articulated around three sections: the first is dedicated to the review of the literature, the second exposes the methodology used and the third discusses the empirical results. 


\section{Literature Review}

Over the past 30 years, floods have killed more than 500,000 people worldwide and resulted in economic losses of more than $\$ 500$ billion [6]. It is therefore not surprising that authors are interested in the population and economic assets exposed to the risk of flooding.

Reference [7] presents an in-depth case study on floods, poverty and climate change in Vietnam and Ho Chi Minh City. In a country such as Vietnam, which is ranked among the five countries most affected by climate change, the authors examine in particular the exposure of the poor to the current flood risks and are interested in how this exposure could evolve with climate change. To do this, they combine flood risk maps and a number of socioeconomic characteristics to measure the distributive impacts of floods at national and local levels. These maps represent the risks of flooding of rivers, floods and coastal areas and provide information on the extent and depth of flood risk in places. Future climate scenarios for return periods of 25, 50, 100 and 200 years are modeled on current climatic conditions and IPCC ${ }^{1}$ estimates. By capturing the flood risk maps thus developed with World Bank estimates of the number of people in each district living below the poverty cutoff (poverty map), the authors show that 33 percent of the Vietnamese population, already exposed, to a flood that occurs every 25 years (with a probability of occurrence of 0.04 ), does not assume any protection. And, under current socioeconomic conditions, climate change can expose 38 to 46 percent of the population, depending on the severity of sea-level rise. In addition, the results of their analysis at city level of Ho Chi Minh provide evidence that poor districts (68 - 85 percent) are more exposed to floods.

Based on the findings of previous work, [8] suggest that shocks caused by natural hazards, particularly floods, are a major reason why people become poor and remain poor. Reference [9] show that the incidence of poverty increased by 12 percent in Bolivia following the 2006 floods. In Peru between 2003 and 2008 an additional catastrophe per year increased poverty rates from 16 to 23 percent at the provincial level [10]. In Mexico, floods and droughts increased poverty levels from 1.5 to 3.7 percent between 2000 and 2005 [11]. Following the cyclone Aila in 2009 in the Shyamnagar district in the southwest of Bangladesh, unemployment and poverty rates rose sharply from 11 to 60 percent and 41 to 63 percent respectively between 2009 and 2010, while per capita income decreased dramatically: 15,000 before the storm and 10,000 after [12]. Reference [8] argue that poor people are more vulnerable to natural disasters such as floods, as their incomes are more dependent on weather, their housing more conducive to health risks, and their assets less protected. The poor also have a lower capacity to adapt to shocks due to lower access to saving, borrowing or social protection.

Reference [13] analyzes the global exposure of poor and non-poor populations to floods and droughts under current climate conditions and to a series of future

${ }^{1}$ Intergovernmental Panel on Climate Change. 
climate scenarios. To this end, global models of hydrological flood data and drought-related hydrological hazards are combined with detailed data on household wealth and income in 52 countries to study the specific exposure to poverty at current and future levels. Thus, with a defined and calculated poverty bias "exposure bias to poverty", the authors find that the poor are often overexposed to droughts and urban floods. With regard to floods, no similar signal for rural households is noted. Furthermore, the exposure bias to poverty remains unchanged in future climate scenarios, although the absolute number of people potentially exposed to floods or droughts may increase or decrease significantly, depending on the scenario and region.

Reference [14] performs a meta-regression analysis of the existing literature in order to examine the direct (first-order) and indirect (higher order) effects of natural disasters on the poor in particular, poverty in society and household welfare measures. The meta-regression is based on documents collected between April and June 2013 on the main search engines: EconLit, Google Scholar, JSTOR, RePec, Wiley Online Library and the World Bank working paper series. Due to the diversity of the available literature, they mainly define the direct and indirect impacts of disasters in terms of income, consumption (direct impact), poverty and wealth indicators (indirect or longer-term), health, education, work and classify disasters according to three types: hydrometeorological catastrophe (mainly floods, precipitation and tropical cyclones), geo-climatological catastrophe (droughts and earthquakes) and grouped natural shocks. At the end of their analysis, they argue that natural disasters have a negative impact on households in general, but especially on low-income poor households. Because these shocks, mainly floods, affect incomes, consumption, household housing, health and education expenditures, they prevent households from emerging from poverty and even pushing them towards deeper poverty.

According to the same findings, studies conducted in Senegal between 2008 and 2009 show that floods are among the shocks that push and/or keep poor households in a vicious circle of poverty. Already, less resilient than others to shocks such as floods, poor households adopt survival strategies involving debt, the sale of goods or the elimination of the education of children and young people, which further aggravates their vulnerability to future shocks [3].

Reference [15], assessing the global and regional evolution of natural hazards and poverty, finds that the poor are overall twice as vulnerable to natural disasters as the non-poor in the twenty-first century. And those are mostly the poorest in East Asia and the Pacific who are most affected, followed by those in South Asia and sub-Saharan Africa. Unlike studies measuring exposure to the average income level, such as gross domestic product (GDP) per capita, Kim specifically examines the geographical distribution of poor people, comparing their level of exposure to natural disasters with that of people non-poor, regional exposure being separately aggregated for the poor and non-poor to identify the gap between them. 


\section{Methodology}

The main objective of this paper is to determine if the poor populations are more victims (if they are not the only victims) floods that have become recurrent in Dakar. To do this, a complete mapping of the various flooded areas of Dakar (in 2009 and 2011) was first carried out. The 2011 household survey was then used to calculate the dimensional and multidimensional poverty rates for the 100 census districts (CDs) in the region. Multidimensional poverty rates are then projected onto so-called flood maps to detect a possible correlation between poverty levels and floods.

\subsection{Floods Maps}

It is the mapping of the main flooded areas of Dakar in October 2009 and 2011. The choice of October is justified by the fact that this month marks the end of the winter period in Dakar, and therefore the flooded areas considered are those that remained under water despite the efforts of evacuation of rainwater (pumping, runoff, evaporation, etc.). For the years, 2005 and 2009 are certainly the years of greatest floods if one refers to the damage and losses caused, but because of the ESPS- $2^{2}$ which was carried out in 2011, the years 2009 (the closest to 2011) and 2011 were selected.

The flood maps are made from satellite images taken under Google Earth at an altitude of $600 \mathrm{~m}$ above the ground, and this for the entire region of Dakar. These images are then geo-referenced and the layers of flooded areas digitized using ArcGIS version 10.2. It should be noted that we have neither estimated the risk nor the depth of the floods. We limited ourselves to delimit the areas that, in 2009 and 2011, were flood victims in Dakar (Figure 1).

In addition, the administrative division of the region of Dakar into district municipalities (2009 administrative division) and the map of the geographical distribution of the 100 census districts in which the ESPS- 2 was carried out, allowed the identification and the allocation to each district of its multidimensional poverty rate. A rate calculated from the characteristics of individuals living in these districts.

\subsection{Multidimensional Poverty Measure}

The multidimensional poverty measurement methodology used in this paper is that proposed by [16] and [17].

\subsubsection{Index $\mathrm{M}_{0}$}

The $\mathrm{M}_{0}$ index belongs to the family of multidimensional poverty proposed by [16] and [17]. This index, also called adjusted staffing ratio, is an appropriate measure when one (or several) of the dimensions to be taken into account is (are) ordinal in nature.

Consider poverty in d dimensions on a population of $n$ individuals. Let $\left[y_{i j}\right]$ the matrix $(n \times d)$ of the realizations of the individuals $i$ on $j$ dimensions, $y_{i j} \geq 0$ ${ }^{2}$ Senegal Poverty Monitoring Sirvey phase 2. 


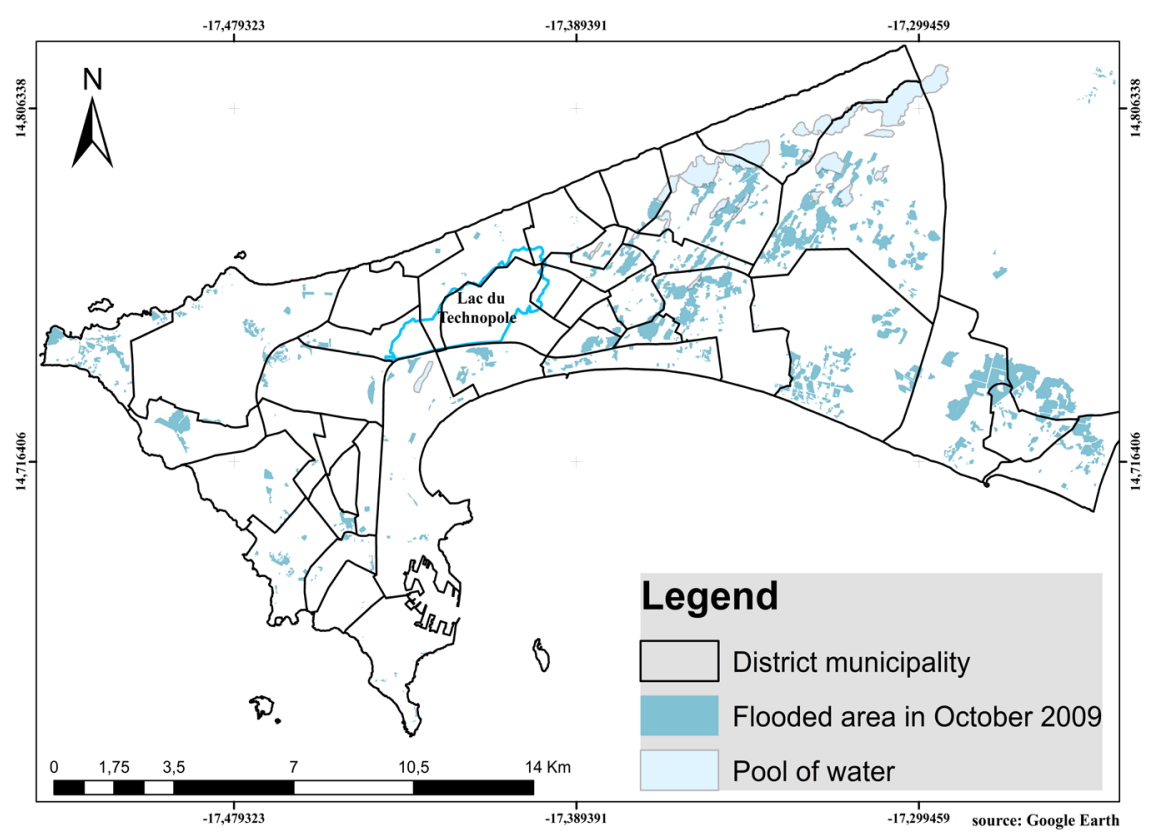

Figure 1. Flooded areas of Dakar in October 2009.

represents the realization of the $i$ individual on all $j$ dimensions. The line vector $y_{i}=\left(y_{i 1}, y_{i 2}, \cdots, y_{i d}\right)$ gives the realizations of the individual $i$ in the different dimensions and the column vector $y_{. j}=\left(y_{1 j}, y_{2 j}, \cdots, y_{n j}\right)$, the distribution of the realizations of individuals in the dimension $j$.

To weight the dimensions, we define a weighting vector $p$ whose $f^{\text {th }}$ element $p_{j}$ represents the weighting of the dimension $j$. Note that $\sum_{j=1}^{d} p_{j}$, i.e. the sum of the dimensional weights is equal to the total number of dimensions. In the case of the multidimensional poverty index, $d=10$.

To identify the poor in the population, a two-step procedure is applied using two types of cutoffs: first, a dimensional poverty line is defined to determine whether or not a person is private in each dimension; secondly, a second multidimensional poverty line is chosen to identify those who should be considered poor.

Let $z_{j}$ the poverty cutoff (or deprivation) for the $j$ dimension, and $z$ the vector of poverty cutoffs. Let $g^{0}=\left[g_{i}^{0}\right]$ a deprivation matrix defined by:

$$
g_{i j}^{0}=\left\{\begin{array}{ll}
p_{j} & \text { si } y_{i j}<z_{j} \\
0 & \text { si } y_{i j}>z_{j}
\end{array} .\right.
$$

In other words, the $i f^{\text {th }}$ entry of the matrix corresponds to the weight $p_{j}$ of the dimension $j$ if the individual $i$ is considered poor in this dimension, and 0 otherwise.

From $g^{0}$, we build a vector of \{intensity of privations\} $\mathcal{c}$, where the $i^{\text {th }}$ entry

$$
c_{i}=\sum_{j=1}^{d} g_{i}^{0}
$$

is the sum of weighted deprivations suffered by an individual $i$. 
The next step is to identify individuals who are poor in the multidimensional sense. To do this, we define a second multidimensional poverty cutoff $k>0$ that we apply to the column vector $c$.

Let $\rho: R_{+}^{d} * R_{++}^{d} \rightarrow\{0,1\}, \rho_{k}$ an identifying function that associates $y_{i} \in R_{+}^{d}$ the vector of the realizations of the individual $i$ and $z \in R_{++}^{d}$ the cutoff vector to an indicator variable.

$$
\rho_{k}\left(y_{i}, z\right)=\left\{\begin{array}{ll}
1 & \text { si } c_{i} \geq k \\
0 & \text { si } c_{i}<k
\end{array} .\right.
$$

An individual is considered poor in the multidimensional sense if the sum of his weighted privations $c_{i}$ is greater than $k$.

To aggregate the information of poor individuals in the population, we construct a second matrix $g^{0}(k)$, obtained from $g^{0}$ by replacing its $i^{\text {th }}$ line $g_{i}^{0}$ by a vector of zeros when $c_{i} \leq k$. This matrix contains the weighted deprivations of the only individuals identified as multidimensionally poor and excludes the deprivations of the non-poor.

Thus, $M_{0}$ is the arithmetic mean of the $g^{0}$ matrix: $M_{0}=\mu\left(g^{0}(k)\right)$ where $\mu$ is the operator of the arithmetic mean.

An important feature of $M_{0}$ is that it can be directly broken down into several indices: the incidence of multidimensional poverty $(H)$ and the intensity of poverty $(A) . H$ is the percentage of individuals who are identified as multidimensionally poor; $H=q / n$ where $q$ is the number of poor individuals. $A$ represents the intensity of multidimensional poverty; $A=\sum_{i=1}^{n} c_{i}(k) / d q$. The $M_{0}$ measure therefore summarizes information on the incidence and intensity of poverty, hence the name of adjusted staffing ratio.

However, [16] and [17] do not specify dimensions, indicators, weights or cutoffs of the $M_{0}$ measure. The latter remains flexible and can be adapted to many contexts.

\subsubsection{Multidimensional Poverty Index (MPI)}

Reference [18] proposed dimensions, indicators, weights and cutoffs for the $M_{0}$ measure. These dimensions, indicators and weights made it possible to build the MPI introduced in 2010 by UNDP in its $20^{\text {th }}$ human development report. MPI is defined as an index of acute multidimensional poverty and allows expressing the multiple deprivations that affect health, education and standard of living of individuals.

The MPI has ten indicators divided into three dimensions $s^{3}$ : nutrition and infant mortality for the health dimension; number of years of schooling and leaving school for the education dimension; electricity, drinking water, sanitary, cooking fuel, flooring and assets for the standard of living. Each dimension has a weighting of one third (33.33\%) and each indicator in one dimension has a

${ }^{3}$ In the description of the MPI, each entry in the matrix $g^{0}$ is called indicator and the term dimension used by Alkire and Foster refers to the conceptual categories (health, education and standard of living) that do not appear directly in the matrix (Alkire and Santos, 2014). 
weight equal to that of the others: $16.67 \%$ for the health and education indicators and $5.56 \%$ for those of standard of living. The Table 1 summarizes the dimensions, indicators, cutoffs and weights of the MPI.

\section{Poverty cutoff $k$}

The poverty cutoff $k$ reflects the sum of the weighted indicators in which an individual must be deprived in order to be considered multidimensionally poor. In the case of the MPI, an individual is identified as multidimensionally poor, if and only if, he suffers from deprivations in at least a third of the weighted indicators $(k=33.33 \%)$. In other words, an individual is poor if he suffers from deprivations in a health indicator and an education indicator, in all six indicators of standard of living, or in three indicators of standard of living and in a health or education indicator.

\subsubsection{A suitable MPI}

\section{Unit of analysis}

To calculate the MPI, [18] considers the household as a unit of analysis. The reason for their choice is that the data needed for comparisons for 104 developing countries were available only for households, which is not our case. Indeed, our ESPS database includes both household (household survey) and individual (individual survey) data. Thus, we consider as unit of analysis the person living in a household because: 1) ideally the MPI would have used the person as a unit

Table 1. Dimensions, indicators, cutoffs and weights of the MPI.

\begin{tabular}{|c|c|c|c|}
\hline Dimension & Indicator & Deprived if... & Weight \\
\hline \multirow[b]{2}{*}{ Health } & Mortality & Any child has died in the family. & $16.67 \%$ \\
\hline & Nutrition & $\begin{array}{l}\text { Any adult or child for whom there is nutritional } \\
\text { information is malnourished. }\end{array}$ & $16.67 \%$ \\
\hline \multirow{2}{*}{ Education } & $\begin{array}{l}\text { Years of } \\
\text { schooling }\end{array}$ & $\begin{array}{l}\text { No household member has completed five years of } \\
\text { schooling. }\end{array}$ & $16.67 \%$ \\
\hline & $\begin{array}{l}\text { Child school } \\
\text { attendance }\end{array}$ & $\begin{array}{l}\text { Any school-aged child is not attending school } \\
\text { in years } 1 \text { to } 8 .\end{array}$ & $16.67 \%$ \\
\hline \multirow{6}{*}{$\begin{array}{l}\text { Standard } \\
\text { of living }\end{array}$} & Electricity & The household has no electricity. & $5.56 \%$ \\
\hline & Water & $\begin{array}{l}\text { The household does not have access to clean drinking } \\
\text { water (according to the MDG guidelines) or clean water } \\
\text { is more than } 30 \text { minutes walking from home. }\end{array}$ & $5.56 \%$ \\
\hline & Sanitation & $\begin{array}{l}\text { The household's sanitation facility is not improved } \\
\text { (according to the MDG guidelines) or it is improved } \\
\text { but shared with other households. }\end{array}$ & $5.56 \%$ \\
\hline & Cooking fuel & The household cooks with dung, wood or charcoal. & $5.56 \%$ \\
\hline & Floor & The household has dirt, sand or dung floor. & $5.56 \%$ \\
\hline & Assets & $\begin{array}{l}\text { The household does not own more than one of: radio, } \\
\text { TV, telephone, bike, motorbike or refrigerator } \\
\text { and does not own a car or truck. }\end{array}$ & $5.56 \%$ \\
\hline
\end{tabular}

Adapted by Alkire and Santos (2014). 
of analysis, which is possible to do with the methodology of Alkire and Foster; 2) a comparison between age and sex groups, for example, is now possible. In our methodology, it is therefore important to note that a person will be considered private in the indicators of standard of living, if the household to which he belongs suffers deprivation in these indicators.

\section{Considered indicators}

It is well known that health is often the most difficult dimension to measure. Reference [18] proposes nutrition and infant mortality as health indicators. However, these indicators are imperfect in many ways. The $20^{\text {th }}$ human development report indicates that health data are of average and very partial quality, particularly with regard to nutrition. Infant mortality is a stock variable that does not specify whether the death of the child occurred in the recent or distant past. Standard malnutrition indicators such as $\mathrm{BMI}^{4}$ for adults and weight of age for children, also appear incomplete. In fact, these indicators do not reflect the micronutrient deficiencies of which some people are victims and consider others as technically malnourished ${ }^{5}$, whereas they are not (the nutritional status of the latter may be due to the type of body and no to poverty).

Due to the lack of consensus on health indicators and because data is a mandatory constraint, our two health indicators differ from those of [18]. In fact, instead of malnutrition, we consider as private in dimension health, any person having difficulties to satisfy ${ }^{6}$ its nutritional needs, often expressed in number of meals, and not in terms of micronutrient intake (indicators of malnutrition have already been criticized). Also, since our unit of analysis is the person living in the household and not the household itself, infant mortality cannot be considered as an indicator. The latter is therefore replaced by the disability variable, which is one of the main health indicators of the ESPS. Indeed, in order to reconcile the results of this study with the objectives of the survey, we consider as private in health, any person living with a disability does not allow him to have a sustained activity or a normal schooling or that his state of health prevents him from working 40 hours a week. For the ESPS, a person who lives with a disability (often due to diseases or accidents poorly supported) testifies to the failure of the sanitary system.

In education, the number of years of schooling, used as a proxy variable for the level of education, is replaced by the latter since it is captured by the survey. Regarding the age of schooling of children, we consider ages 7 to 12 because, in Senegal, the school officially starts at 7 years old. For the standard of living, the indicators remain unchanged and each person is assigned the characteristics of the household in which he lives. Table 2 summarizes the dimensions, indicators, cutoffs and weights of our MPI.

\footnotetext{
${ }^{4}$ Body Mass Index.

${ }^{5}$ Adults are considered malnourished if their BMI is below 18.5. Children are considered malnourished if their z-score of weight-for-age is below minus two standard deviations from the median of the reference population.

${ }^{6}$ For the ESPS "satisfied" means that the minimum requirements are filled, neither more nor less.
} 
Table 2. Dimensions, indicators, cutoffs and weights of our MPI.

\begin{tabular}{|c|c|c|c|}
\hline Dimension & Indicator & Deprived if... & Weight \\
\hline \multirow[b]{2}{*}{ Health } & Nutrition & $\begin{array}{l}\text { The person has difficulty to meet its nutritional needs, } \\
\text { often expressed in number of meals, excluding } \\
\text { micronutrient intakes. }\end{array}$ & $16.67 \%$ \\
\hline & Disability & $\begin{array}{l}\text { The person lives with a disability that does not allow him } \\
\text { to have a sustained activity or normal schooling or that } \\
\text { his state of health prevents him from working } 40 \text { hours a } \\
\text { week. }\end{array}$ & $16.67 \%$ \\
\hline \multirow{2}{*}{ Education } & $\begin{array}{l}\text { Level of } \\
\text { education }\end{array}$ & $\begin{array}{c}\text { The person has a level of education lower than } \\
\text { primary education. }\end{array}$ & $16.67 \%$ \\
\hline & $\begin{array}{l}\text { Child school } \\
\text { attendance }\end{array}$ & $\begin{array}{l}\text { The child of school-aged has left school before } 12 \\
\text { (for ages } 7 \text { to 12). }\end{array}$ & $16.67 \%$ \\
\hline \multirow{6}{*}{$\begin{array}{l}\text { Standard } \\
\text { of living }\end{array}$} & Electricity & $\begin{array}{l}\text { The household in which the person lives has } \\
\text { no electricity. }\end{array}$ & $5.56 \%$ \\
\hline & Water & $\begin{array}{l}\text { The household in which the person lives does not have } \\
\text { access to clean drinking water } \\
\text { (according to the MDG guidelines) or clean water is more } \\
\text { than } 30 \text { minutes walking from home. }\end{array}$ & $5.56 \%$ \\
\hline & Sanitation & $\begin{array}{l}\text { The household in which the person lives does not have } \\
\text { improved sanitation (according to the MDG guidelines) } \\
\text { or it is improved but shared with other households. }\end{array}$ & $5.56 \%$ \\
\hline & Cooking fuel & $\begin{array}{l}\text { The household in which the person lives cooks } \\
\text { with dung, wood or charcoal. }\end{array}$ & $5.56 \%$ \\
\hline & Floor & $\begin{array}{l}\text { The household in which the person lives has dirt, } \\
\text { sand or dung floor. }\end{array}$ & $5.56 \%$ \\
\hline & Assets & $\begin{array}{l}\text { The household in which the person lives does not own } \\
\text { more than one of: radio, TV, telephone, bike, motorbike } \\
\text { or refrigerator and does not own a car or truck. }\end{array}$ & $5.56 \%$ \\
\hline
\end{tabular}

Adapted by the authors.

\section{Results}

\subsection{Presentation of the Database}

The database used in this paper comes from the poverty monitoring survey in Senegal second phase (ESPS-2) carried out in 2011 by the national agency for statistics and demography. The objectives of this survey were essentially based on information on indicators for monitoring living conditions, poverty and the Millennium Development Goals (MDGs). ESPS-2 collected information on the education, health, heritage, comfort ... of 17,891 sampled households in the country. The details and sampling methods used are to be found in [2].

The region of Dakar alone has a total of 1,638 households (about one-tenth of the total number of households) divided into two types: urban households (90\%) and rural households (10\%) located only in the department of Rufisque. In total of 13,398 individuals were surveyed, of whom 12,683 lived in urban-type house- 
holds and 715 in rural-type households. Regarding the distribution among the four (4) departments in the region, we counted 3340 individuals in Dakar; 3,308 in Guédiawaye; 3710 in Pikine and 3040 in Rufisque [2].

On these individuals, ESPS collected information on individual characteristics such as age, sex, ethnicity, religion, marital status and so on. It also found information on the level of education, the current attendance of the school (especially for children), cohabitation with a disability preventing the interviewee from having a sustained activity or attending normal schooling or even work 40 hours a week. At the level of the households in which the interviewees live we collected, among other variables, the type of toilet, the main source of drinking water, the main source of fuel for cooking, access to electricity, the main soil material and the holding of assets.

\subsection{Empirical Results}

Given the dimensions, indicators, weights and cutoffs retained (Table 2), we estimate that a significant portion of the population of Dakar suffers from deprivation in all indicators. Large disparities are, however, noted between the departments of Dakar (the least affected by the floods), Pikine (most affected by floods), Guédiawaye and Rufisque and even within the departments (Tables S1-S4). Indeed, in health dimension, we estimate at $20.6 \%$ the percentage of individuals suffering from deprivation in the nutrition indicator: more than a fifth of the population of Dakar believes that their nutritional needs are not met. This percentage falls to $19.6 \%$ in the department of Dakar against $25.4 \%$ in the department of Pikine. The proportion of people suffering from a disability that prevents them from carrying on a normal activity or working 40 hours a week amounts to $2.2 \%$ for the region, $1.7 \%$ for Dakar (department), $2.4 \%$ for Pikine and $3.2 \%$ for Rufisque (Table 3).

At the same time, $46.1 \%$ of people over the age of 12 have lower levels of education than primary school and, as a result, are deprived according to this indicator. However, there is hope for a significant drop in this rate for the years to come, since in 2011 the percentage of children of school age who did not attend school was estimated at $0.2 \%$. And more, we note that the percentage of children

Table 3. Dimensional and multidimensional poverty rates of the four (4) departments of the region of Dakar.

\begin{tabular}{|c|c|c|c|c|c|c|c|c|c|c|c|c|}
\hline \multirow[b]{2}{*}{ Department } & \multicolumn{2}{|c|}{ Health } & \multicolumn{2}{|c|}{ Education } & \multicolumn{6}{|c|}{ Standard of living } & \multicolumn{2}{|c|}{ MPI } \\
\hline & Disability & Nutrition & $\begin{array}{l}\text { Child school } \\
\text { attendance }\end{array}$ & $\begin{array}{c}\text { Level of } \\
\text { education }\end{array}$ & Electricity & Water & Sanitation & $\begin{array}{l}\text { Cooking } \\
\text { fuel }\end{array}$ & Floor & Assets & Rate & A \\
\hline Dakar & $1.7 \%$ & $19.6 \%$ & $0.2 \%$ & $42.3 \%$ & $2.2 \%$ & $0.7 \%$ & $2.2 \%$ & $20.5 \%$ & $3.8 \%$ & $49.6 \%$ & $21.7 \%$ & 1.4 \\
\hline Pikine & $2.4 \%$ & $25.4 \%$ & $0.2 \%$ & $48.3 \%$ & $10.1 \%$ & $3.4 \%$ & $1.0 \%$ & $37.5 \%$ & $14.9 \%$ & $78.6 \%$ & $32.6 \%$ & 1.6 \\
\hline Rufisque & $3.2 \%$ & $15.8 \%$ & $0.4 \%$ & $48.6 \%$ & $7.4 \%$ & $1.6 \%$ & $4.3 \%$ & $42.9 \%$ & $10.1 \%$ & $61.7 \%$ & $23.2 \%$ & 1.3 \\
\hline Region & $2.2 \%$ & $20.6 \%$ & $0.2 \%$ & $46.1 \%$ & $6.4 \%$ & $1.7 \%$ & $2.0 \%$ & $32.6 \%$ & $8.2 \%$ & $63.1 \%$ & $25.3 \%$ & 5.7 \\
\hline
\end{tabular}

Calculation of authors. 
absent from school remains low overall in all departments even if Rufisque is above average $(0.4 \%)$.

Regarding the indicators of standard of living, we estimate that $6.4 \%$ of the population of Dakar lives in households without access to electricity. The department of Dakar has the lowest deprivation rate while Pikine has one-tenth of its population without electricity. $3.4 \%$ of interviewees in Pikine also live in households without access to clean drinking water ${ }^{7}$ or that water is more than 30 minutes walk from their household, when the regional rate is $1.7 \%$. Although the main cooking fuel used in Dakar is gas, the fact remains that $32.6 \%$ of households use wood (6.3\%), charcoal (23.5\%) or combine the two fuels indifferently (2.8\%); manure (or animal waste) is not used by households in Dakar at all. The proportion of households without adequate sanitation ${ }^{8}$ is $2.0 \%$ and all indicators, the latter is the only one for which the department of Dakar has a higher deprivation rate than Pikine; Rufisque totaling the largest number of private persons with a rate of $4.3 \%$. In terms of the main soil material, $8.2 \%$ of households are covered with sand or banco, and once again, Pikine has a much higher rate of deprivation than other departments. When we look at the assets held by households in Dakar, we note a deprivation rate of $63 \%$ due in part to that of Pikine which reaches $78 \%$. In other words, more than $78 \%$ of the population of Pikine live in households with no more than one of the equipment listed in Table 2. In total, in this department, we estimate at $13.2 \%$ the percentage of individuals suffering from deprivation in at least three (3) indicators of standard of living (average deprivation) and at $0.6 \%$ the percentage of private individuals in the six (6) dimension indicators. In other words, in 2011, $0.6 \%$ of the population of Pikine lived in households without access to drinking water or electricity and whose main soil material is sand or banco; uses as the main cooking fuel wood and/or charcoal and does not have adequate sanitation even less assets.

At the end, we estimate that $25.3 \%$ of the population of Dakar is multidimensionally poor with a poverty intensity of 5.7 and a calculated MPI of 0.011 . At the departmental level, Dakar has the lowest multidimensional poverty rate (21.7\%) and the lowest rates of deprivation. In contrast, the department of Pikine has the highest multidimensional poverty rate $(32.6 \%)$ and the largest number of poor people in the dimensional sense. Indeed, on all indicators (with the exception of sanitation only), deprivation rates of Pikine exceed the regional average and often correspond to maxima.

In addition, the flood maps (Figures 2-5) reveal that at the departmental level, the nearest CDs flooded areas or even those most affected by floods note the highest poverty rates. This is the case, for example, of Malika, located in the area of lowlands and natural water reserves, which has the highest poverty rate (53.3\%, maximum of maxima), Djiddah Kao (51.6\% and 45.8\%), Diamaguene/ Sicap Mbao (49.3\%), Guinao Rail Nord and Sud with respectively $43.2 \%$ and

${ }^{7}$ The tap water of households is considered clean drinking water.

${ }^{8}$ Only sewers, flush toilets and latrines covered are considered to meet the criteria for adequate sanitation. 


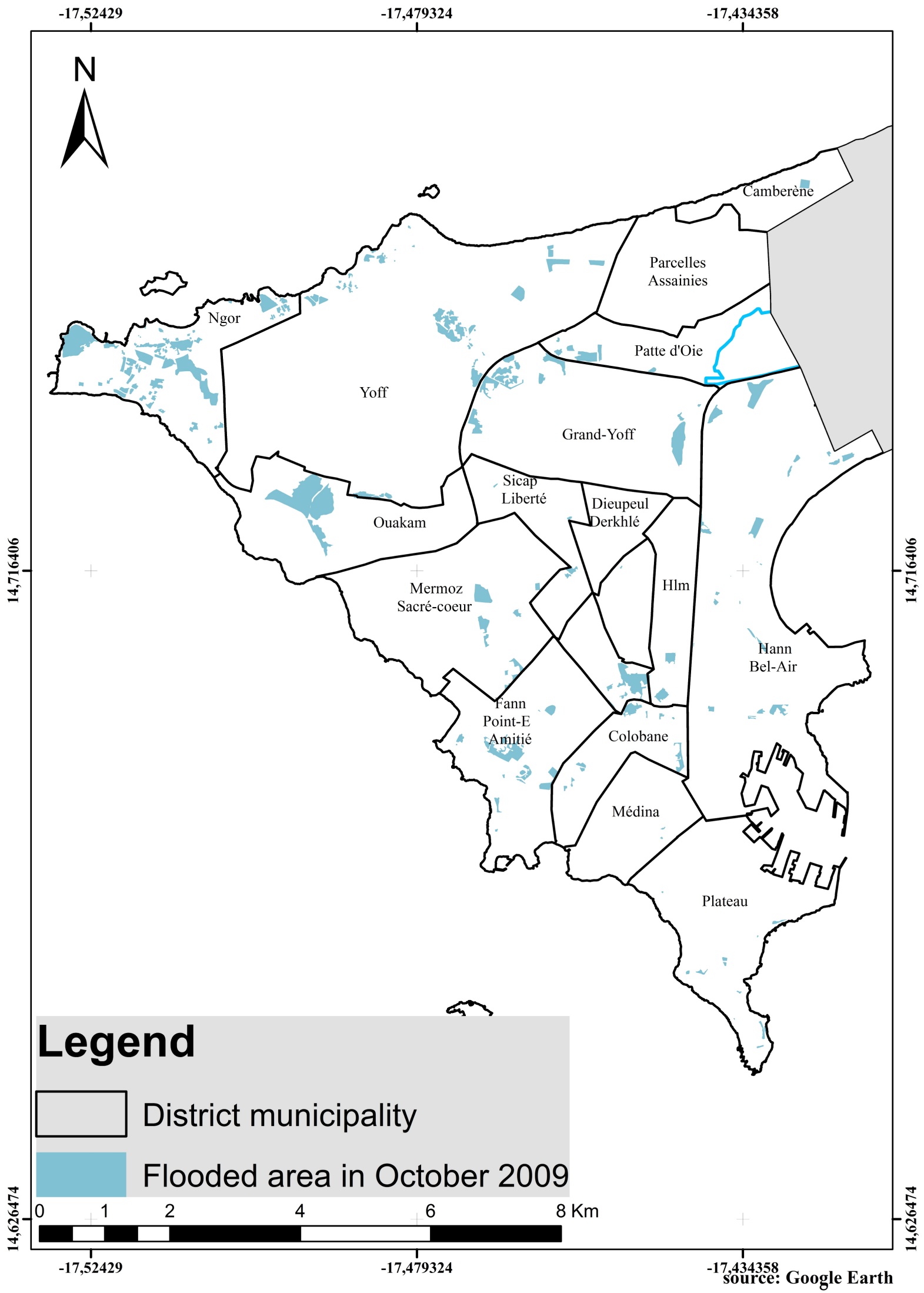

(a) 


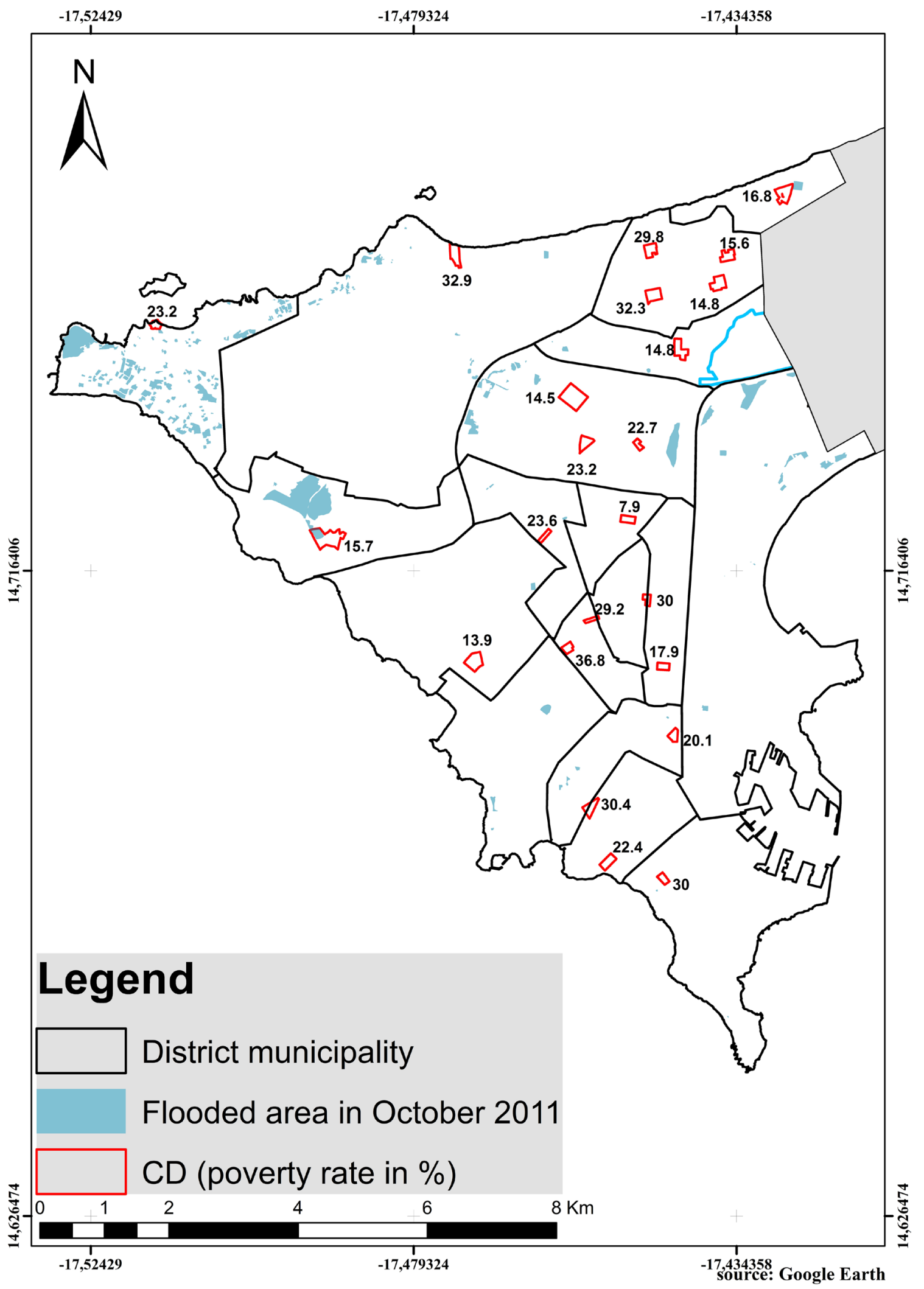

(b)

Figure 2. Flooded areas of Dakar (departement) in October 2009 (a) and 2011 (b); In red on part (b), the census districts of ESPS-2 and their corresponding multidimensional poverty rate. 


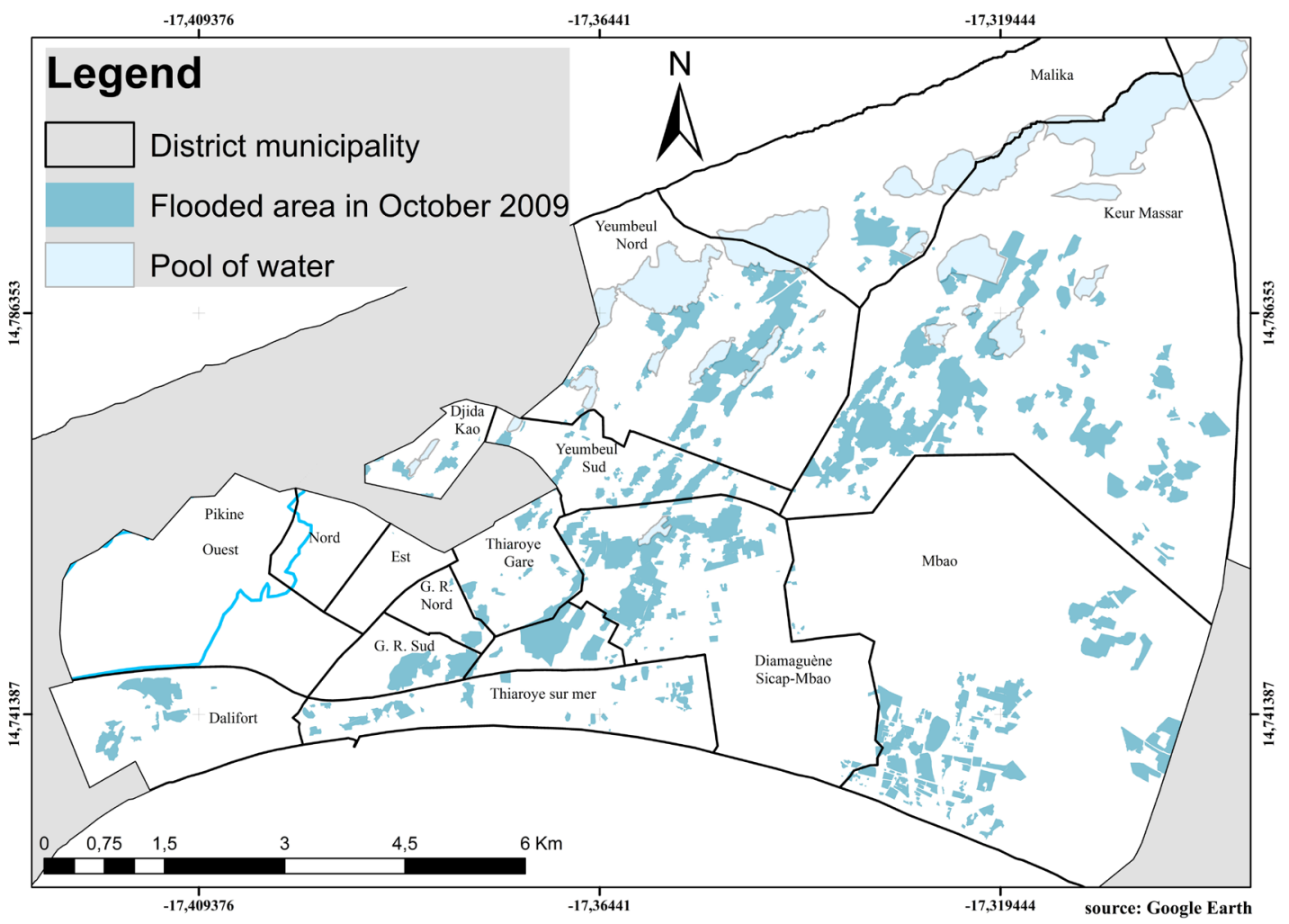

(a)

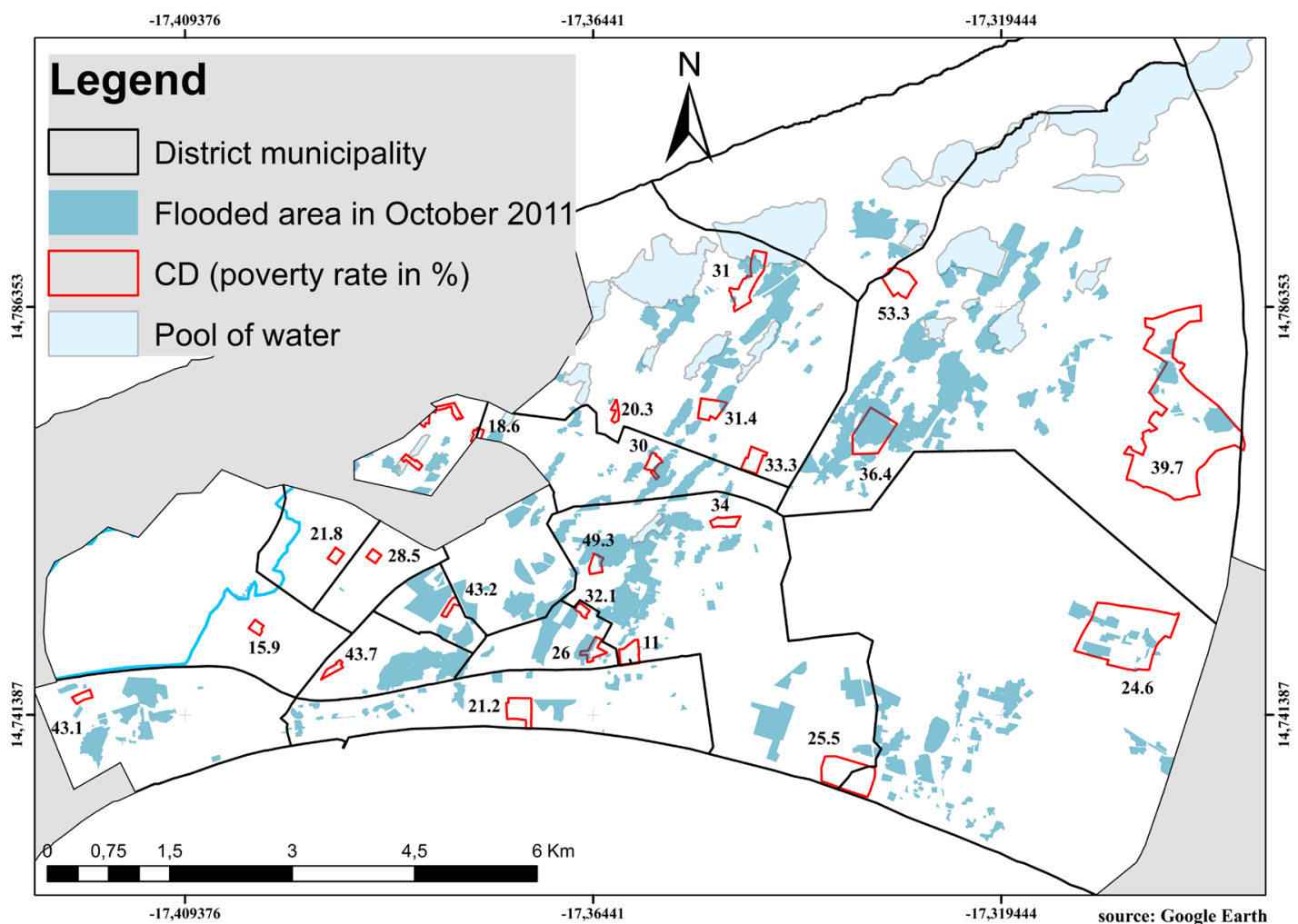

(b)

Figure 3. Flooded areas of Pikine in October 2009 (a) and 2011 (b). In red on part (b), the census districts of ESPS-2 and their corresponding multidimensional poverty rate. 


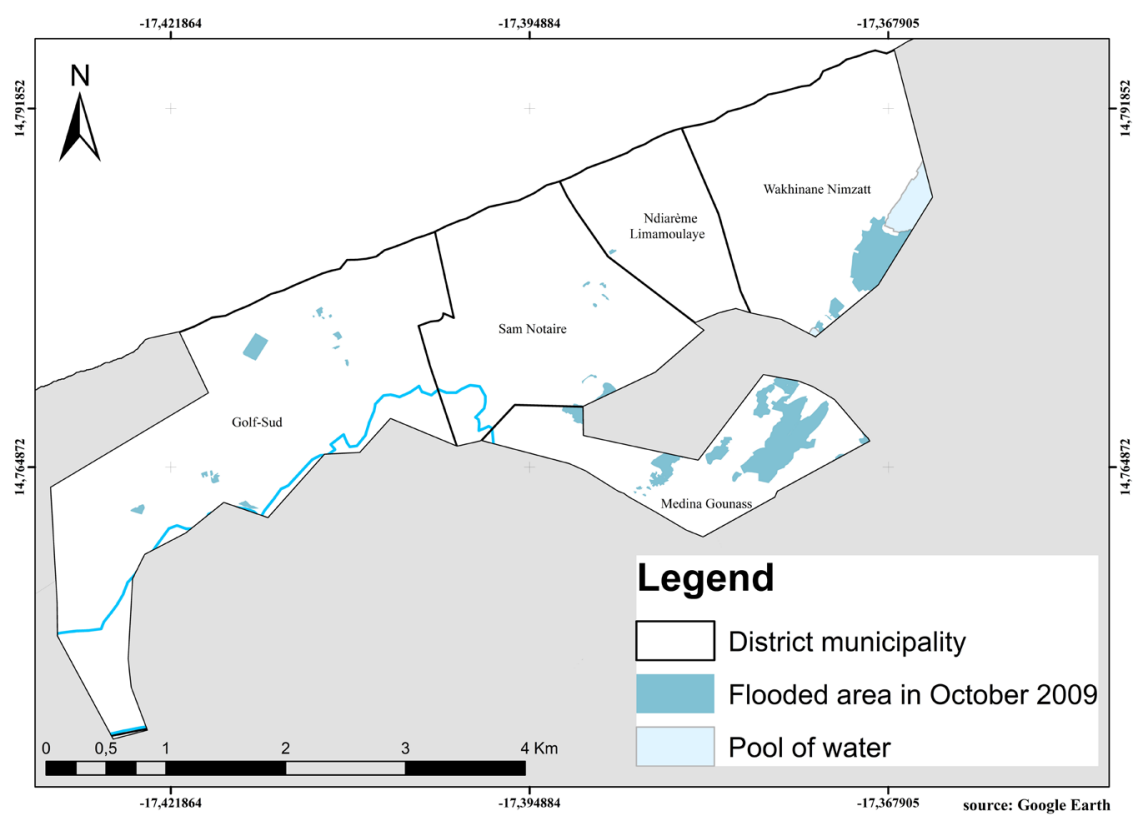

(a)

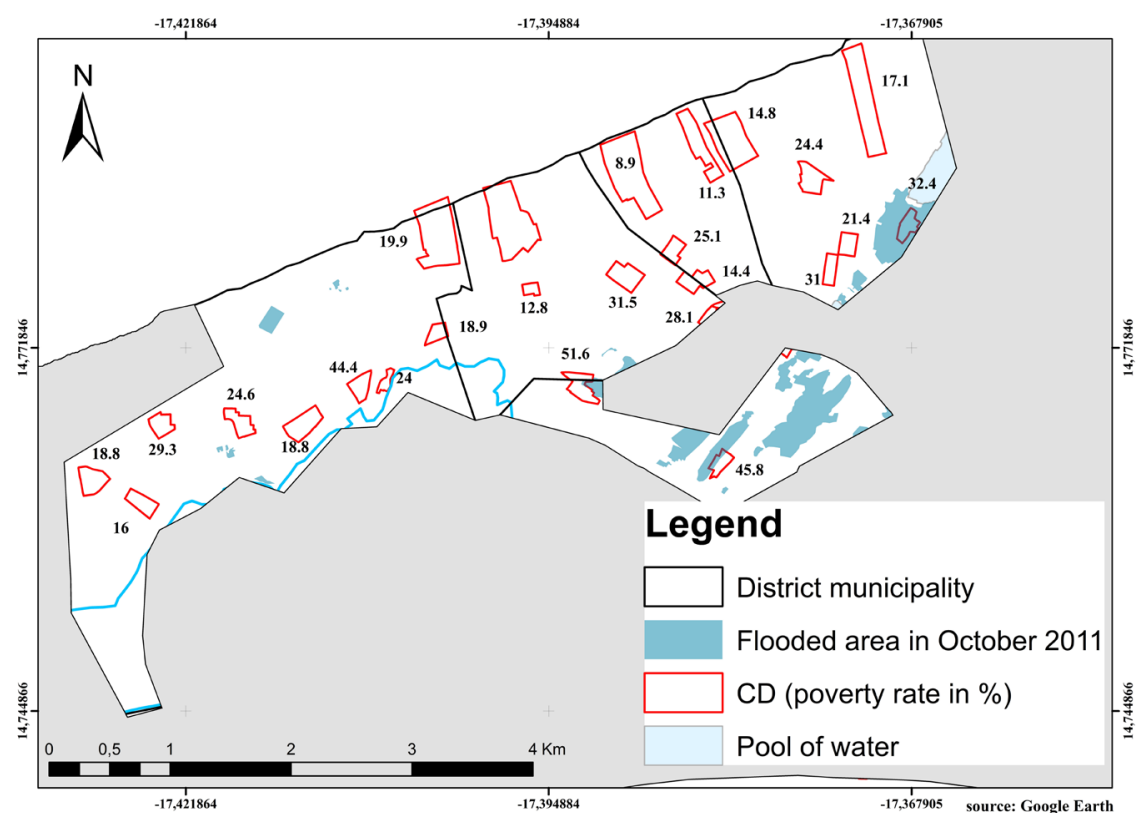

(b)

Figure 4. Flooded areas of Guediawaye in October 2009 (a) and 2011 (b). In red on part (b) the census districts of ESPS- 2 and their corresponding multidimensional poverty rate.

43.7\% and Dalifort (43.1\%), all located in the department of Pikine (Figure 3). In these localities where floods occurred in 2009 as well as in 2011, people suffer deprivation in the health and education indicators (level of education and nutritional needs in particular), indicators which combined are enough to consider a person as multidimensionally poor. Added to this are deprivations of which they suffer in the ownership of assets and the cooking fuel used. These populations are ever poorer than they do not have a higher level of education than primary 


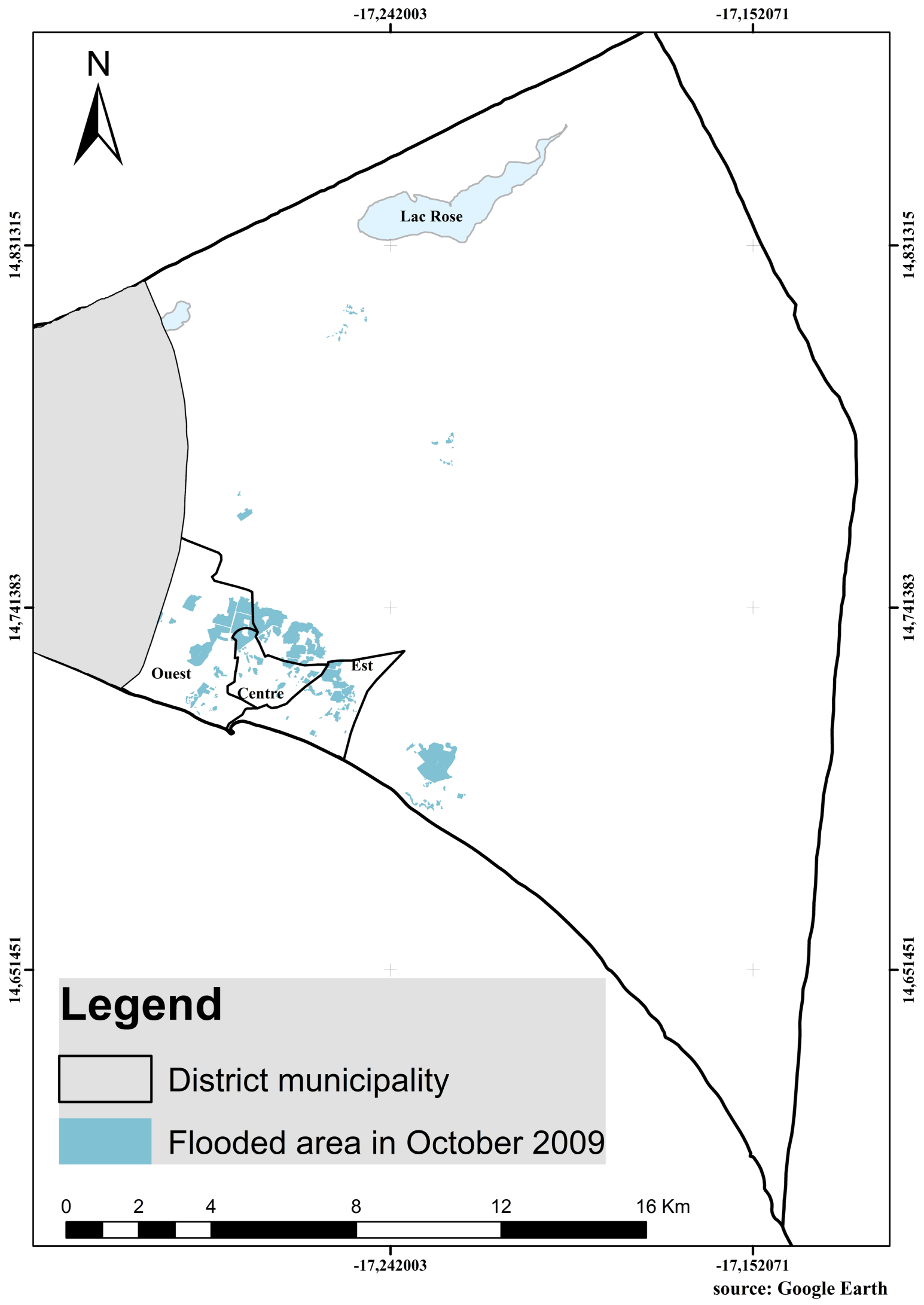

(a) 


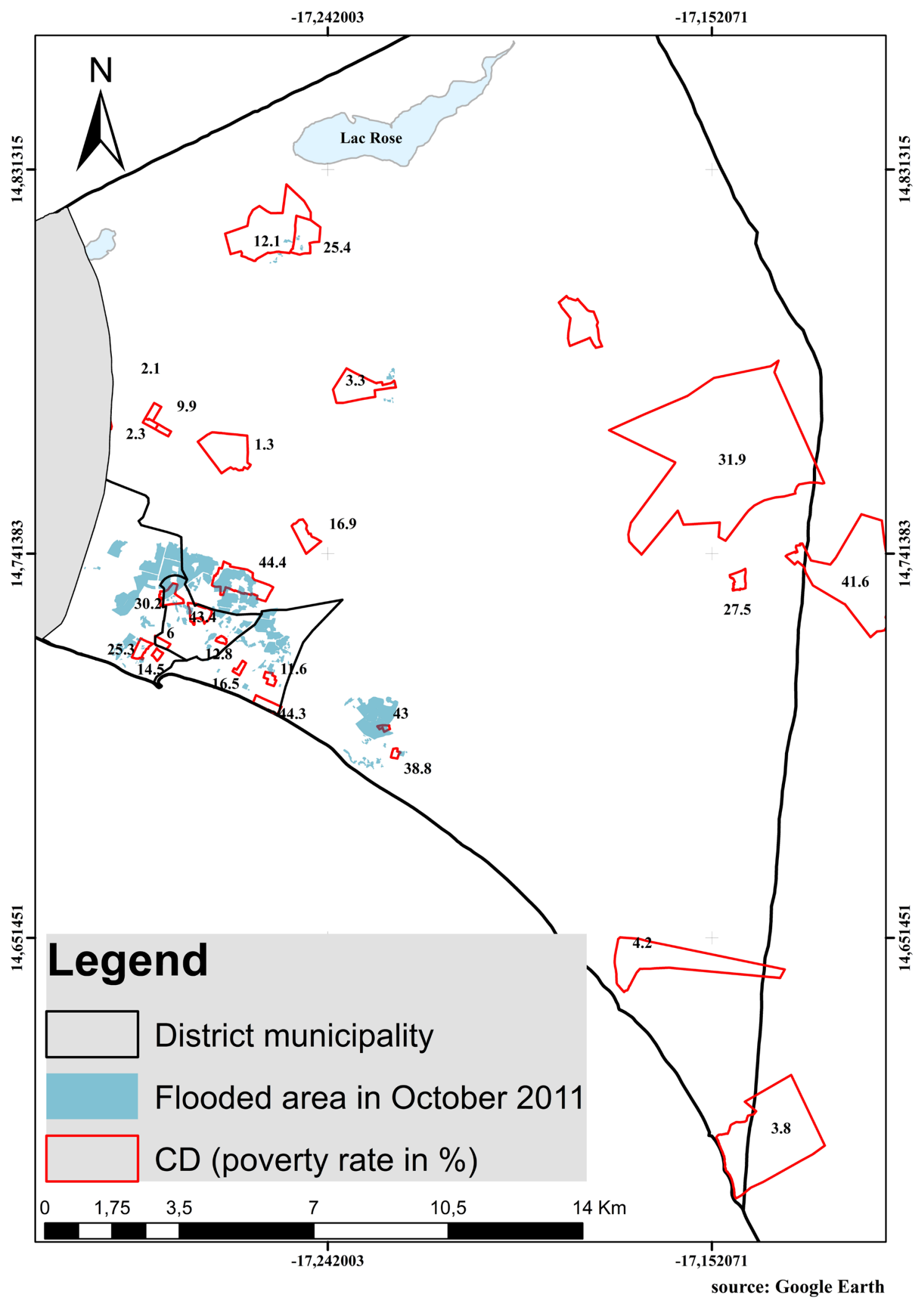

(b)

Figure 5. Flooded areas of Rufisque in October 2009 (a) and 2011 (b) in red on part (b), the census districts of ESPS-2 and their corresponding multidimensional poverty rate. 
education and fail to meet their food needs properly. In addition, they live in households whose main cooking fuel is considered inadequate, do not have assets and they do not always have access to electricity.

In Guédiawaye, such levels of poverty are never equaled, but districts like those of Gold Sud (44.4\%), Nimzatt (32.4\% and 31.0\%), Sam Notary (31.5\%) and Medina Gounass (30.4\%) (straddling Pikine and Guédiawaye) have more than 3 poor people out of 10 inhabitants (Figure 4). These people suffer deprivation in the same indicators as those found in Pikine and emphasize the relevance of our indicators. Indeed, although our indicators are not monetary, we know that a poor person has difficulty to satisfy his nutritional needs, often has a low level of education and does not have decent housing.

In the department of Dakar where the flooded areas mainly correspond to unoccupied empty spaces (land, parking, etc.) and there is a clear decrease in these areas between 2009 and 2011 due to real estate development, poverty rates remain globally mixed. At Yoff, we would attempt to explain the poverty rate (32.9\%) by the fact that the population is essentially Lebou and lives in traditional-type homes (often private in all three (3) indicators of standard of living (floor, assets and fuel)). However, this reasoning contrasts with the results of Ngor (23.2\%) and Ouakam (15.7\%) who concentrate the same Lebou population and who, nevertheless, note relatively low poverty rates. In Fann/Point-E (36.8\%), Parcelles Assainies (32.3\%) and HLM (30.8\%), almost a third of the population is considered multidimensionally poor, although they have not been flooded in any way. However, it is also important to note that the districts with the lowest poverty rates ( 7 to $15 \%$ ) have never recorded floods (Figure 2).

With regard to the department of Rufisque and depending on whether we are in urban or rural areas, we observed fairly contradictory levels of poverty (1.3\% for the less poor census district compared to $44.4 \%$ for the poorest in the multidimensional sense). Indeed, in Sangalkam (1.3\% and 3.3\%), Jaxaay (2.1\% and 2.3\%) and Yene (3.8\% and $4.2 \%)$, all non-flooded and rural-type, population have no great difficulty to meet their food needs (often expressed in number of meals). And, all things being equal elsewhere, the very low levels of poverty in these areas can be explained by the null scores of the nutrition indicator (strongly correlated with the multidimensional poverty rate $(87.4 \%)$ ). For urban-type districts, floods are noted in both 2009 and 2011, and as a result poverty rates remain close to those of Pikine. This is the case, for example Nord Rufisque (44.4\% and 43.4\%), Est Rufisque (44.3\%) and Bargny (43\% and 38.8\%) (Figure 5).

\section{Conclusions}

Thanks to the new multidimensional poverty measure introduced by the UNDP in its 20th human development report, this work made it possible to estimate the multidimensional poverty index (MPI) of the region of Dakar. This index of 0.011 corresponding to a poverty rate of $25.3 \%$ (i.e. a quarter of the population of Dakar) is relatively lower than the monetary poverty index given the ANSD (26.1\%) 
and therefore differs from the MPI calculated by [18]. Indeed, the MPIs calculated by Alkire and Santos are often above the monetary poverty index because of the overestimation of certain indicators such as mortality and nutrition. For our MPI, the analysis base being the individual and not the household, health indicators in particular has not been over-estimated.

This work has also made it possible to oppose the multidimensional and dimensional poverty rates of the department of Dakar, considered the least affected by the floods, to those of Pikine, the most affected by the floods. The proportion of multidimensionally poor individuals in Dakar (department) is estimated at $21.7 \%$, compared to $32.6 \%$ in Pikine, $22.7 \%$ in Guédiawaye and $23.2 \%$ in Rufisque (Table 3). Poverty rates derive from dimensional rates such as nutrition (with respectively $19.6 \%, 25.4 \%, 20.4 \%$, and $15.8 \%$ of private persons in the departments of Dakar, Pikine, Guédiawaye and Rufisque), level of education ( $42.3 \%$, $48.3 \%, 45.2 \%$ and $48.6 \%)$, cooking fuel $(20.5 \%, 37.5 \%, 29.9 \%$ and $42.9 \%)$ and assets $(49.6 \%, 78.6 \%, 60.8 \%$ and $61.7 \%)$. In other words, more than one in five people in Dakar, Guédiawaye, Rufisque and three out of 10 people in Pikine are considered multidimensionally poor because they cannot adequately meet their food needs (often expressed in number of meals) and have a level of education at most equal to that of primary, which pre-dispose them to poverty. We recall that these two indicators, combined, make it possible to estimate a person as poor. In addition, they live in households whose main cooking fuel is considered inadequate and do not have more than one asset. Thus, although there is hope for a significant drop in deprivation levels of the education level indicator (the most correlated to the multidimensional poverty rate), poverty reduction strategies will necessarily require monitoring and keeping of children at school to a level at least higher than that of primary school.

This work has, and above all, shown that the poorest populations in the region of Dakar are those who are victims of floods and are mainly located in the departments of Pikine, Guédiawaye and Rufisque. In Pikine, where floods were experienced in 2005, 2009 and 2011, poverty rates crossed the 50\% line while they are located in Guédiawaye and Rufisque districts at around 30\% and 40\%. One particularity is, however, noted in Rufisque (the only department with $10 \%$ of rural households): the very low levels of poverty can be explained by the nullity of the nutrition indicator scores, strongly and positively correlated to the multidimensional poverty rate. These floods highlight the failure of spatial planning policies taken by uncontrolled soil occupation because the flooded areas in Pikine and Guédiawaye often correspond to lowlands and natural water reserves.

However, it should be noted that this work was not done without major constraints. The administrative divisions, constantly changing, have made it often difficult to correctly identify district municipalities and therefore to locate certain districts between Pikine and Guédiawaye. In Rufisque, only three district municipalities have been demarcated and some districts, supposed to be in the department, even come out of the administrative boundaries of the region. In addition, the 
satellite images with which we digitized the flooded areas for the year 2011, presented several cloudy areas. For these areas, we made cross-checks with August 2011 or simply leave without any treatment because the intersected images also presented clouds. The flooded areas of 2011 presented on the maps can, therefore, be victims of under/over-estimation.

\section{Acknowledgements}

We gratefully acknowledge the financial support for this project by Unit for Mathematical and Computer Modeling of Complex Systems (UMMISCO).

\section{References}

[1] Fond monétaire international (2013) Document de strategie de réduction de la pauvreté-Note consultative conjointe sur la stratégie nationale de développement économique et social.

[2] Agence Nationale de la Statistique et de la Démographie (2013) Deuxième Enquête de Suivi de la Pauvreté au Sénégal. Rapport définitif.

[3] Dramani, L., Cissé, R. and Fall, A.S. (2010) Impacts intergénérationnels des chocs sur la pauvreté des ménages au Sénégal: Cas des inondations, incendie, perte de récoltes. Laboratoire de Recherche sur les Transformations économiques et Sociales (LARTES/IFAN).

[4] Agence Nationale de la Statistique et de la Démographie (2010) Situation économique et sociale régionale du Senegal en 2009.

[5] Agence Nationale de la Statistique et de la Démographie (2015) Situation économique et sociale régionale 2013 .

[6] Kocornik, M., Michaels, T. and Rauch, F. (2015) Flooded Cities. CEP Discussion Paper 1398.

[7] Bangalore, M., Smith, A. and Veldkamp, T. (2016) Exposure to Floods, Climate Change, and Poverty in Vietnam. Policy Research Working Paper 7765, World Bank.

[8] Hallegatte, S., Bangalore, M., Bonzanigo, L., Fay, M., Kane, T., Narloch, U., Rozenberg, J., Treguer, D. and Vogt-Schilb, A. (2016) Shock Waves: Managing the Impacts of Climate Change on Poverty. Climate Change and Development Series. World Bank, Washington DC.

[9] Perez-De-Rada, E. and Paz, D. (2008) Análisisde la Relación entre Amenazas Naturales y Condiciones de Vida: El Caso de Bolivia. Research Report, United Nations Development Programme.

[10] Glave, M., Fort, R. and Rosemberg, C. (2008) Disaster Risk and Poverty in Latin America: The Peruvian Case Study. Research Report, United Nations Development Programme.

[11] Rodriguez-Oreggia, E., De La Fuente, A., De La Torre, R. and Moreno, H.A. (2013) Natural Disasters, Human development and Poverty at the Municipal Level in Mexico. The Journal of Development Studies, 49, 442-455. https://doi.org/10.1080/00220388.2012.700398

[12] Akter, S. and Mallick, B. (2013) The Poverty-Vulnerability-Resilience Nexus: Evidence from Bangladesh. Ecological Economics, 96, 114-124.

https://doi.org/10.1016/j.ecolecon.2013.10.008

[13] Winsemius, H.C., Jongman, B., Veldkamp, T.I.E., Hallegatte, S., Bangalore, M. and 
Ward, P. (2015) Disaster Risk, Climate Change, and Poverty: Assessing the Global Exposure of Poor People to Floods and Droughts. Policy Research Working Paper 7480, World Bank.

[14] Karim, A. and Noy, I. (2014) Poverty and Natural Disasters: A Meta-Analysis. School of Economics and Finance Working Paper, Victoria University of Wellington, Wellington.

[15] Kim, N. (2012) How Much More Exposed Are the Poor to Natural Disasters? Global and Regional Measurement. Disasters, 36, 195-211. https://doi.org/10.1111/j.1467-7717.2011.01258.x

[16] Alkire, S. and Foster, J. (2007) Counting and Multidimensional Poverty Measurement. Oxford Poverty and Human Development Initiative, Working Paper 7, Oxford Department of International Development, University of Oxford, Oxford.

[17] Alkire, S. and Foster, J. (2009) Counting and Multidimensional Poverty. In: Von Braun, J., Ed., The Poorest and Hungry: Assessment, Analysis and Actions, International Food Policy Research Institute, Washington DC.

[18] Alkire, S. and Santos, M.E. (2014) Measuring Acute Poverty in the Developing World: Robustness and Scope of the Multidimensional Poverty Index. World Development, 59, 251-274. https://doi.org/10.1016/j.worlddev.2014.01.026 


\section{Appendix}

Table S1. Dimensional and multidimensional poverty rates by census district (CD), Department of Dakar.

\begin{tabular}{|c|c|c|c|c|c|c|c|c|c|c|c|}
\hline \multirow{2}{*}{ Department } & \multicolumn{2}{|c|}{ Health } & \multicolumn{2}{|c|}{ Education } & \multicolumn{6}{|c|}{ Standard of living } & \multirow{2}{*}{$\begin{array}{l}\text { MPI } \\
\text { Rate }\end{array}$} \\
\hline & Disability & Nutrition & $\begin{array}{l}\text { Child school } \\
\text { attendance }\end{array}$ & $\begin{array}{l}\text { Level of } \\
\text { education }\end{array}$ & Electricity & Water & Sanitation & $\begin{array}{c}\text { Cooking } \\
\text { fuel }\end{array}$ & Floor & Assets & \\
\hline Plateau & $2.7 \%$ & $21.8 \%$ & $0.9 \%$ & $57.3 \%$ & $1.8 \%$ & $0.0 \%$ & $0.0 \%$ & $44.5 \%$ & $7.3 \%$ & $86.4 \%$ & $30.0 \%$ \\
\hline Medina & $1.2 \%$ & $18.8 \%$ & $0.0 \%$ & $42.4 \%$ & $2.4 \%$ & $8.2 \%$ & $2.4 \%$ & $15.3 \%$ & $8.2 \%$ & $56.5 \%$ & $22.4 \%$ \\
\hline Medina & $3.6 \%$ & $12.4 \%$ & $0.0 \%$ & $45.1 \%$ & $7.1 \%$ & $0.0 \%$ & $0.0 \%$ & $31.0 \%$ & $0.0 \%$ & $66.4 \%$ & $15.9 \%$ \\
\hline Colobane & $0.0 \%$ & $26.5 \%$ & $0.0 \%$ & $40.2 \%$ & $3.9 \%$ & $0.0 \%$ & $0.0 \%$ & $43.1 \%$ & $3.9 \%$ & $68.6 \%$ & $30.4 \%$ \\
\hline Colobane & $2.0 \%$ & $14.1 \%$ & $1.3 \%$ & $52.3 \%$ & $0.0 \%$ & $0.0 \%$ & $6.7 \%$ & $54.4 \%$ & $6.7 \%$ & $42.3 \%$ & $20.1 \%$ \\
\hline Fann/Point E & $3.2 \%$ & $36.8 \%$ & $0.0 \%$ & $55.8 \%$ & $6.3 \%$ & $0.0 \%$ & $0.0 \%$ & $18.9 \%$ & $0.0 \%$ & $80.0 \%$ & $36.8 \%$ \\
\hline Grand Dakar & $0.8 \%$ & $26.2 \%$ & $0.0 \%$ & $47.7 \%$ & $1.5 \%$ & $0.0 \%$ & $0.0 \%$ & $2.3 \%$ & $0.0 \%$ & $73.1 \%$ & $29.2 \%$ \\
\hline Biscuiterie & $4.6 \%$ & $27.8 \%$ & $0.0 \%$ & $47.4 \%$ & $3.8 \%$ & $0.0 \%$ & $0.8 \%$ & $35.3 \%$ & $12.0 \%$ & $62.4 \%$ & $30.8 \%$ \\
\hline HLM & $1.2 \%$ & $16.0 \%$ & $0.0 \%$ & $29.0 \%$ & $0.6 \%$ & $0.0 \%$ & $0.0 \%$ & $13.0 \%$ & $0.0 \%$ & $27.2 \%$ & $17.9 \%$ \\
\hline Hann/Bel-Air & $2.7 \%$ & $9.5 \%$ & $0.0 \%$ & $21.6 \%$ & $0.0 \%$ & $0.0 \%$ & $0.0 \%$ & $1.4 \%$ & $0.0 \%$ & $9.5 \%$ & $9.5 \%$ \\
\hline Sicap/Liberté & $2.4 \%$ & $22.0 \%$ & $0.0 \%$ & $28.5 \%$ & $0.0 \%$ & $0.0 \%$ & $0.0 \%$ & $0.0 \%$ & $0.0 \%$ & $22.8 \%$ & $23.6 \%$ \\
\hline Dieuppeul & $1.1 \%$ & $6.8 \%$ & $0.5 \%$ & $38.9 \%$ & $0.0 \%$ & $0.0 \%$ & $0.0 \%$ & $7.4 \%$ & $0.0 \%$ & $28.4 \%$ & $7.9 \%$ \\
\hline Ouakam & $2.4 \%$ & $12.0 \%$ & $0.0 \%$ & $53.6 \%$ & $12.7 \%$ & $0.0 \%$ & $1.2 \%$ & $9.0 \%$ & $7.8 \%$ & $70.5 \%$ & $15.7 \%$ \\
\hline Ngor & $1.1 \%$ & $20.5 \%$ & $0.0 \%$ & $56.8 \%$ & $4.9 \%$ & $0.0 \%$ & $8.6 \%$ & $23.8 \%$ & $2.2 \%$ & $38.9 \%$ & $23.2 \%$ \\
\hline Yoff & $0.8 \%$ & $32.5 \%$ & $0.9 \%$ & $49.1 \%$ & $0.0 \%$ & $2.2 \%$ & $0.0 \%$ & $49.1 \%$ & $14.5 \%$ & $65.8 \%$ & $32.9 \%$ \\
\hline Mermoz & $0.0 \%$ & $13.9 \%$ & $0.0 \%$ & $22.2 \%$ & $1.9 \%$ & $0.0 \%$ & $0.0 \%$ & $0.0 \%$ & $0.0 \%$ & $12.0 \%$ & $13.9 \%$ \\
\hline Grand-Yoff & $2.7 \%$ & $21.3 \%$ & $0.0 \%$ & $44.7 \%$ & $0.0 \%$ & $0.0 \%$ & $0.0 \%$ & $15.3 \%$ & $0.0 \%$ & $62.0 \%$ & $22.7 \%$ \\
\hline Grand-Yofff & $1.1 \%$ & $23.2 \%$ & $0.0 \%$ & $36.8 \%$ & $1.1 \%$ & $0.0 \%$ & $0.0 \%$ & $6.3 \%$ & $0.0 \%$ & $46.3 \%$ & $23.2 \%$ \\
\hline Grand-Yoff & $1.8 \%$ & $14.5 \%$ & $0.0 \%$ & $23.1 \%$ & $0.0 \%$ & $0.0 \%$ & $0.0 \%$ & $0.0 \%$ & $0.0 \%$ & $37.6 \%$ & $14.5 \%$ \\
\hline Patte d'Oie & $2.0 \%$ & $13.4 \%$ & $0.0 \%$ & $30.9 \%$ & $6.7 \%$ & $0.0 \%$ & $0.0 \%$ & $8.1 \%$ & $0.0 \%$ & $20.1 \%$ & $1.8 \%$ \\
\hline P. Assainies & $3.6 \%$ & $13.8 \%$ & $0.9 \%$ & $41.3 \%$ & $0.0 \%$ & $10.1 \%$ & $34.9 \%$ & $7.3 \%$ & $0.0 \%$ & $56.0 \%$ & $15.6 \%$ \\
\hline P. Assainies & $0.8 \%$ & $13.9 \%$ & $0.0 \%$ & $46.7 \%$ & $0.0 \%$ & $0.0 \%$ & $0.0 \%$ & $5.7 \%$ & $0.0 \%$ & $47.5 \%$ & $14.8 \%$ \\
\hline P. Assainies & $0.0 \%$ & $32.3 \%$ & $0.0 \%$ & $30.0 \%$ & $0.0 \%$ & $0.0 \%$ & $0.0 \%$ & $10.0 \%$ & $0.0 \%$ & $42.3 \%$ & $32.3 \%$ \\
\hline P. Assainies & $0.8 \%$ & $21.4 \%$ & $0.0 \%$ & $36.6 \%$ & $0.0 \%$ & $0.0 \%$ & $3.1 \%$ & $24.4 \%$ & $11.5 \%$ & $80.9 \%$ & $29.8 \%$ \\
\hline Camberene & $1.1 \%$ & $16.8 \%$ & $0.0 \%$ & $54.3 \%$ & $0.0 \%$ & $0.0 \%$ & $0.0 \%$ & $46.7 \%$ & $9.8 \%$ & $40.8 \%$ & $16.8 \%$ \\
\hline Dakar & $1.7 \%$ & $19.6 \%$ & $0.2 \%$ & $42.3 \%$ & $2.2 \%$ & $0.7 \%$ & $2.2 \%$ & $20.5 \%$ & $3.8 \%$ & $49.6 \%$ & $21.7 \%$ \\
\hline
\end{tabular}

Calculation of authors. 
Table S2. Dimensional and multidimensional poverty rates by census district (CD), Department of Pikine.

\begin{tabular}{|c|c|c|c|c|c|c|c|c|c|c|c|}
\hline \multirow{2}{*}{ Department } & \multicolumn{2}{|c|}{ Health } & \multicolumn{2}{|c|}{ Education } & \multicolumn{6}{|c|}{ Standard of living } & \multirow{2}{*}{$\begin{array}{l}\text { MPI } \\
\text { Rate }\end{array}$} \\
\hline & Disability & Nutrition & $\begin{array}{l}\text { Child school } \\
\text { attendance }\end{array}$ & $\begin{array}{l}\text { Level of } \\
\text { education }\end{array}$ & Electricity & Water & Sanitation & $\begin{array}{l}\text { Cooking } \\
\text { fuel }\end{array}$ & Floor & Assets & \\
\hline Yeumbeul Nord & $0.0 \%$ & $29.6 \%$ & $0.6 \%$ & $47.8 \%$ & $25.8 \%$ & $2.5 \%$ & $0.0 \%$ & $48.4 \%$ & $6.3 \%$ & $76.7 \%$ & $31.4 \%$ \\
\hline Yeumbeul Nord & $3.6 \%$ & $18.5 \%$ & $0.0 \%$ & $54.8 \%$ & $19.6 \%$ & $7.1 \%$ & $7.1 \%$ & $33.9 \%$ & $7.1 \%$ & $79.2 \%$ & $31.0 \%$ \\
\hline Yeumbeul Nord & $2.6 \%$ & $17.7 \%$ & $0.0 \%$ & $9.4 \%$ & $1.3 \%$ & $6.3 \%$ & $0.0 \%$ & $67.1 \%$ & $1.3 \%$ & $79.7 \%$ & $20.3 \%$ \\
\hline Yeumbeul Nord & $3.3 \%$ & $31.0 \%$ & $0.5 \%$ & $50.0 \%$ & $6.5 \%$ & $5.6 \%$ & $0.0 \%$ & $15.7 \%$ & $2.3 \%$ & $69.4 \%$ & $33.3 \%$ \\
\hline Diack Sao & $2.2 \%$ & $24.7 \%$ & $0.9 \%$ & $44.5 \%$ & $22.0 \%$ & $0.0 \%$ & $0.0 \%$ & $19.8 \%$ & $7.9 \%$ & $68.3 \%$ & $26.0 \%$ \\
\hline Diack Sao & $1.4 \%$ & $27.0 \%$ & $0.7 \%$ & $38.7 \%$ & $8.0 \%$ & $16.8 \%$ & $2.9 \%$ & $9.5 \%$ & $3.6 \%$ & $67.9 \%$ & $32.1 \%$ \\
\hline Yeumbeul Sud & $3.5 \%$ & $25.7 \%$ & $0.0 \%$ & $50.0 \%$ & $12.9 \%$ & $0.0 \%$ & $0.0 \%$ & $60.0 \%$ & $11.4 \%$ & $72.9 \%$ & $30.0 \%$ \\
\hline Malika & $1.2 \%$ & $37.9 \%$ & $0.6 \%$ & $52.7 \%$ & $27.8 \%$ & $26.0 \%$ & $0.0 \%$ & $56.2 \%$ & $36.1 \%$ & $90.5 \%$ & $53.3 \%$ \\
\hline Keur Massar & $0.6 \%$ & $26.3 \%$ & $0.0 \%$ & $48.6 \%$ & $5.6 \%$ & $9.5 \%$ & $0.0 \%$ & $32.4 \%$ & $40.8 \%$ & $95.0 \%$ & $39.7 \%$ \\
\hline Keur Massar & $1.2 \%$ & $32.1 \%$ & $0.0 \%$ & $39.4 \%$ & $5.5 \%$ & $0.0 \%$ & $0.0 \%$ & $21.8 \%$ & $0.0 \%$ & $93.9 \%$ & $36.4 \%$ \\
\hline Pikine Ouest & $4.5 \%$ & $12.4 \%$ & $0.0 \%$ & $57.5 \%$ & $1.8 \%$ & $0.0 \%$ & $0.0 \%$ & $32.7 \%$ & $4.4 \%$ & $61.1 \%$ & $15.9 \%$ \\
\hline Pikine Est & $4.2 \%$ & $22.4 \%$ & $0.0 \%$ & $53.9 \%$ & $2.4 \%$ & $0.0 \%$ & $0.0 \%$ & $45.5 \%$ & $10.3 \%$ & $90.3 \%$ & $28.5 \%$ \\
\hline Pikine Nord & $7.0 \%$ & $18.8 \%$ & $1.0 \%$ & $45.5 \%$ & $5.9 \%$ & $0.0 \%$ & $0.0 \%$ & $22.8 \%$ & $3.0 \%$ & $80.2 \%$ & $21.8 \%$ \\
\hline Dalifort & $3.0 \%$ & $17.6 \%$ & $0.0 \%$ & $48.8 \%$ & $12.7 \%$ & $5.9 \%$ & $10.8 \%$ & $44.1 \%$ & $37.3 \%$ & $70.6 \%$ & $43.1 \%$ \\
\hline Djiddah Kao & $2.3 \%$ & $7.0 \%$ & $0.0 \%$ & $58.7 \%$ & $5.2 \%$ & $0.0 \%$ & $0.0 \%$ & $72.1 \%$ & $29.7 \%$ & $67.4 \%$ & $18.6 \%$ \\
\hline Djiddah Kao & $3.9 \%$ & $34.0 \%$ & $0.0 \%$ & $57.5 \%$ & $0.0 \%$ & $0.0 \%$ & $0.0 \%$ & $49.7 \%$ & $23.5 \%$ & $77.8 \%$ & $45.8 \%$ \\
\hline Djiaddah Kao & $3.2 \%$ & $45.1 \%$ & $0.0 \%$ & $51.6 \%$ & $23.0 \%$ & $0.0 \%$ & $0.0 \%$ & $47.5 \%$ & $9.0 \%$ & $94.3 \%$ & $51.6 \%$ \\
\hline Guinao Rail Nord & $0.0 \%$ & $43.2 \%$ & $0.0 \%$ & $40.5 \%$ & $0.0 \%$ & $0.0 \%$ & $0.0 \%$ & $43.2 \%$ & $0.0 \%$ & $54.1 \%$ & $43.2 \%$ \\
\hline Guinao Rail Sud & $2.5 \%$ & $37.8 \%$ & $0.0 \%$ & $49.6 \%$ & $3.4 \%$ & $0.0 \%$ & $0.0 \%$ & $36.1 \%$ & $19.3 \%$ & $72.3 \%$ & $43.7 \%$ \\
\hline Thiaroye sur Mer & $2.3 \%$ & $18.9 \%$ & $0.0 \%$ & $39.4 \%$ & $6.1 \%$ & $0.0 \%$ & $2.3 \%$ & $18.9 \%$ & $14.4 \%$ & $57.6 \%$ & $21.1 \%$ \\
\hline Diamaguene & $1.9 \%$ & $32.3 \%$ & $0.5 \%$ & $53.5 \%$ & $1.4 \%$ & $0.0 \%$ & $0.0 \%$ & $72.4 \%$ & $32.3 \%$ & $97.2 \%$ & $49.3 \%$ \\
\hline Diamaguene & $2.9 \%$ & $9.8 \%$ & $0.0 \%$ & $32.4 \%$ & $9.2 \%$ & $1.2 \%$ & $0.0 \%$ & $22.5 \%$ & $15.6 \%$ & $68.8 \%$ & $11.0 \%$ \\
\hline Diamaguene & $1.4 \%$ & $26.1 \%$ & $0.0 \%$ & $44.4 \%$ & $15.7 \%$ & $0.0 \%$ & $0.0 \%$ & $25.5 \%$ & $7.8 \%$ & $95.5 \%$ & $34.0 \%$ \\
\hline Mbao & $3.3 \%$ & $16.8 \%$ & $0.0 \%$ & $49.7 \%$ & $10.1 \%$ & $0.0 \%$ & $0.0 \%$ & $24.8 \%$ & $24.2 \%$ & $61.7 \%$ & $25.5 \%$ \\
\hline Mbao & $0.8 \%$ & $23.8 \%$ & $0.0 \%$ & $45.2 \%$ & $7.1 \%$ & $0.0 \%$ & $4.8 \%$ & $22.2 \%$ & $3.2 \%$ & $89.7 \%$ & $24.6 \%$ \\
\hline Pikine & $2.4 \%$ & $25.4 \%$ & $0.2 \%$ & $48.3 \%$ & $10.1 \%$ & $3.4 \%$ & $1.0 \%$ & $37.5 \%$ & $14.9 \%$ & $78.6 \%$ & $32.6 \%$ \\
\hline
\end{tabular}

Calculation of authors. 
Table S3. Dimensional and multidimensional poverty rates by census district (CD), Department of Guédiawaye.

\begin{tabular}{|c|c|c|c|c|c|c|c|c|c|c|c|}
\hline \multirow{2}{*}{ Department } & \multicolumn{2}{|c|}{ Health } & \multicolumn{2}{|c|}{ Education } & \multicolumn{6}{|c|}{ Standard of living } & \multirow{2}{*}{$\begin{array}{l}\text { MPI } \\
\text { Rate }\end{array}$} \\
\hline & Disability & Nutrition & $\begin{array}{l}\text { Child school } \\
\text { attendance }\end{array}$ & $\begin{array}{l}\text { Level of } \\
\text { education }\end{array}$ & Electricity & Water & Sanitation & $\begin{array}{l}\text { Cooking } \\
\text { fuel }\end{array}$ & Floor & Assets & \\
\hline Golf Sud & $4.0 \%$ & $20.0 \%$ & $0.0 \%$ & $40.0 \%$ & $0.0 \%$ & $0.0 \%$ & $0.0 \%$ & $0.0 \%$ & $0.0 \%$ & $64.0 \%$ & $24.0 \%$ \\
\hline Golf Sud & $3.2 \%$ & $43.7 \%$ & $0.0 \%$ & $38.9 \%$ & $18.3 \%$ & $0.0 \%$ & $0.0 \%$ & $41.3 \%$ & $12.7 \%$ & $59.5 \%$ & $44.4 \%$ \\
\hline Golf Sud & $2.5 \%$ & $16.9 \%$ & $0.6 \%$ & $50.0 \%$ & $1.9 \%$ & $0.0 \%$ & $0.0 \%$ & $29.9 \%$ & $0.0 \%$ & $84.4 \%$ & $18.8 \%$ \\
\hline Golf Sud & $1.4 \%$ & $14 . \%$ & $0.0 \%$ & $34.2 \%$ & $5.5 \%$ & $12.3 \%$ & $5.5 \%$ & $18.5 \%$ & $5.5 \%$ & $52.1 \%$ & $19.9 \%$ \\
\hline Golf Sud & $0.9 \%$ & $22.8 \%$ & $0.0 \%$ & $46.5 \%$ & $0.9 \%$ & $0.0 \%$ & $0.9 \%$ & $8.8 \%$ & $0.9 \%$ & $49.1 \%$ & $24.6 \%$ \\
\hline Golf Sud & $1.1 \%$ & $28.7 \%$ & $0.0 \%$ & $41.5 \%$ & $0.0 \%$ & $0.0 \%$ & $0.0 \%$ & $25.0 \%$ & $0.0 \%$ & $63.8 \%$ & $29.3 \%$ \\
\hline Golf Sud & $1.5 \%$ & $18.0 \%$ & $0.0 \%$ & $45.1 \%$ & $0.0 \%$ & $0.0 \%$ & $0.0 \%$ & $6.8 \%$ & $0.0 \%$ & $35.3 \%$ & $18.8 \%$ \\
\hline Golf Sud & $1.2 \%$ & $14.8 \%$ & $0.0 \%$ & $32.1 \%$ & $0.0 \%$ & $0.0 \%$ & $0.0 \%$ & $11.1 \%$ & $0.0 \%$ & $63.0 \%$ & $16.0 \%$ \\
\hline Sam Notaire & $1.6 \%$ & $29.8 \%$ & $0.0 \%$ & $51.6 \%$ & $2.4 \%$ & $0.0 \%$ & $0.8 \%$ & $30.6 \%$ & $7.3 \%$ & $69.4 \%$ & $31.5 \%$ \\
\hline Sam Notaire & $0.6 \%$ & $12.3 \%$ & $0.0 \%$ & $54.2 \%$ & $0.0 \%$ & $0.0 \%$ & $0.0 \%$ & $43.0 \%$ & $0.0 \%$ & $77.1 \%$ & $12.8 \%$ \\
\hline Sam Notaire & $3.3 \%$ & $17.8 \%$ & $0.0 \%$ & $49.4 \%$ & $1.1 \%$ & $0.0 \%$ & $0.0 \%$ & $43.9 \%$ & $5.0 \%$ & $60.0 \%$ & $18.9 \%$ \\
\hline Limamoulaye & $0.9 \%$ & $14.4 \%$ & $1.8 \%$ & $46.8 \%$ & $4.5 \%$ & $0.0 \%$ & $0.0 \%$ & $23.4 \%$ & $0.0 \%$ & $46.8 \%$ & $14.4 \%$ \\
\hline Limamoulaye & $0.6 \%$ & $22.2 \%$ & $0.0 \%$ & $48.0 \%$ & $2.9 \%$ & $0.0 \%$ & $0.0 \%$ & $45.0 \%$ & $5.8 \%$ & $46.2 \%$ & $25.1 \%$ \\
\hline Limamoulaye & $0.8 \%$ & $6.5 \%$ & $0.0 \%$ & $28.2 \%$ & $4.8 \%$ & $4.8 \%$ & $4.8 \%$ & $6.5 \%$ & $4.8 \%$ & $28.2 \%$ & $11.3 \%$ \\
\hline Limamoulaye & $0.9 \%$ & $8.0 \%$ & $0.0 \%$ & $24.1 \%$ & $0.0 \%$ & $0.0 \%$ & $0.0 \% 6$ & $3.6 \%$ & $0.0 \%$ & $24.1 \%$ & $31.0 \%$ \\
\hline Nimzatt & $1.6 \%$ & $31.0 \%$ & $0.0 \%$ & $49.2 \%$ & $7.9 \%$ & $0.0 \%$ & $0.0 \%$ & $18.3 \%$ & $0.0 \%$ & $72.2 \%$ & $31.0 \%$ \\
\hline Nimzatt & $0.6 \%$ & $18.8 \%$ & $1.3 \%$ & $43.5 \%$ & $13.0 \%$ & $0.0 \%$ & $0.0 \%$ & $66.9 \%$ & $7.1 \%$ & $67.5 \%$ & $21.4 \%$ \\
\hline Nimzatt & $1.9 \%$ & $18.6 \%$ & $0.0 \%$ & $50.0 \%$ & $22.4 \%$ & $0.0 \%$ & $5.1 \%$ & $30.8 \%$ & $0.0 \%$ & $70.5 \%$ & $24.4 \%$ \\
\hline Nimzatt & $1.2 \%$ & $27.6 \%$ & $0.0 \%$ & $57.1 \%$ & $10.0 \%$ & $6.5 \%$ & $0.0 \%$ & $33.5 \%$ & $9.4 \%$ & $81.2 \%$ & $32.4 \%$ \\
\hline Nimzatt & $2.6 \%$ & $16.2 \%$ & $0.0 \%$ & $33.3 \%$ & $0.0 \%$ & $0.0 \%$ & $0.0 \%$ & $51.3 \%$ & $0.0 \%$ & $61.5 \%$ & $17.1 \%$ \\
\hline Nimzatt & $0.8 \%$ & $14.8 \%$ & $0.0 \%$ & $32.0 \%$ & $0.0 \%$ & $0.0 \%$ & $0.0 \%$ & $14.8 \%$ & $0.0 \%$ & $28.7 \%$ & $14.8 \%$ \\
\hline Gounass & $2.0 \%$ & $18.0 \%$ & $0.0 \%$ & $54.6 \%$ & $6.2 \%$ & $0.0 \%$ & $0.0 \%$ & $34.5 \%$ & $2.6 \%$ & $62.9 \%$ & $21.1 \%$ \\
\hline Gounass & $0.8 \%$ & $27.3 \%$ & $0.0 \%$ & $54.7 \%$ & $3.1 \%$ & $0.0 \%$ & $0.0 \%$ & $36.7 \%$ & $14.8 \%$ & $85.9 \%$ & $28.1 \%$ \\
\hline Gounass & $3.4 \%$ & $22.3 \%$ & $0.0 \%$ & $52.0 \%$ & $20.3 \%$ & $0.0 \%$ & $0.0 \%$ & $37.8 \%$ & $0.0 \%$ & $79.1 \%$ & $30.4 \%$ \\
\hline Guédiawaye & $1.6 \%$ & $20.4 \%$ & $0.2 \%$ & $45.2 \%$ & $5.6 \%$ & $1.1 \%$ & $0.7 \%$ & $29.9 \%$ & $3.3 \%$ & $60.8 \%$ & $22.7 \%$ \\
\hline
\end{tabular}

Calculation of authors. 
Table S4. Dimensional and multidimensional poverty rates by census district (CD), Department of Rufisque.

\begin{tabular}{|c|c|c|c|c|c|c|c|c|c|c|c|}
\hline \multirow{2}{*}{ Department } & \multicolumn{2}{|c|}{ Health } & \multicolumn{2}{|c|}{ Education } & \multicolumn{6}{|c|}{ Standard of living } & \multirow{2}{*}{$\begin{array}{l}\text { MPI } \\
\text { Rate }\end{array}$} \\
\hline & Disability & Nutrition & $\begin{array}{l}\text { Child school } \\
\text { attendance }\end{array}$ & $\begin{array}{l}\text { Level of } \\
\text { education }\end{array}$ & Electricity & Water & Sanitation & $\begin{array}{c}\text { Cooking } \\
\text { fuel }\end{array}$ & Floor & Assets & \\
\hline Rufisque Ouest & $0.0 \%$ & $23.6 \%$ & $0.0 \%$ & $38.5 \%$ & $3.4 \%$ & $3.4 \%$ & $3.4 \%$ & $22.4 \%$ & $3.4 \%$ & $59.8 \%$ & $25.3 \%$ \\
\hline Rufisque Ouest & $4.9 \%$ & $12.4 \%$ & $0.0 \%$ & $46.9 \%$ & $17.2 \%$ & $0.0 \%$ & $0.0 \%$ & $15.9 \%$ & $0.0 \%$ & $76.6 \%$ & $14.5 \%$ \\
\hline Rufisque Nord & $2.1 \%$ & $28.8 \%$ & $0.0 \%$ & $43.2 \%$ & $4.3 \%$ & $0.0 \%$ & $0.0 \%$ & $25.9 \%$ & $5.8 \%$ & $81.3 \%$ & $30.2 \%$ \\
\hline Rufisque Nord & $0.7 \%$ & $5.3 \%$ & $0.0 \%$ & $41.1 \%$ & $0.0 \%$ & $0.0 \%$ & $0.0 \%$ & $7.3 \%$ & $0.0 \%$ & $70.2 \%$ & $6.0 \%$ \\
\hline Rufisque Nord & $4.1 \%$ & $35.2 \%$ & $0.0 \%$ & $45.1 \%$ & $0.0 \%$ & $0.0 \%$ & $0.0 \%$ & $45.1 \%$ & $13.9 \%$ & $31.1 \%$ & $43.4 \%$ \\
\hline Rufisque Nord & $1.1 \%$ & $11.7 \%$ & $0.6 \%$ & $49.4 \%$ & $2.8 \%$ & $0.0 \%$ & $2.8 \%$ & $16.7 \%$ & $1.7 \%$ & $62.2 \%$ & $12.8 \%$ \\
\hline Rufisque Nord & $3.5 \%$ & $26.8 \%$ & $0.7 \%$ & $44.4 \%$ & $26.8 \%$ & $0.0 \%$ & $28.9 \%$ & $35.2 \%$ & $22.5 \%$ & $68.3 \%$ & $44.4 \%$ \\
\hline Rufisque Est & $2.3 \%$ & $43.7 \%$ & $1.9 \%$ & $60.1 \%$ & $0.0 \%$ & $0.0 \%$ & $8.2 \%$ & $45.6 \%$ & $0.0 \%$ & $86.7 \%$ & $44.3 \%$ \\
\hline Rufisque Est & $2.8 \%$ & $13.6 \%$ & $0.0 \%$ & $43.8 \%$ & $0.6 \%$ & $0.0 \%$ & $0.0 \%$ & $17.6 \%$ & $2.8 \%$ & $49.4 \%$ & $16.5 \%$ \\
\hline Rufisque Est & $3.5 \%$ & $7.5 \%$ & $1.2 \%$ & $53.2 \%$ & $4.0 \%$ & $0.0 \%$ & $4.6 \%$ & $57.2 \%$ & $12.7 \%$ & $43.9 \%$ & $11.6 \%$ \\
\hline Bargny & $3.2 \%$ & $28.1 \%$ & $1.6 \%$ & $53.9 \%$ & $13.3 \%$ & $0.0 \%$ & $8.6 \%$ & $56.2 \%$ & $32.0 \%$ & $69.5 \%$ & $43.0 \%$ \\
\hline Bargny & $1.7 \%$ & $31.0 \%$ & $0.0 \%$ & $39.7 \%$ & $11.2 \%$ & $0.0 \%$ & $6.0 \%$ & $31.0 \%$ & $9.5 \%$ & $52.6 \%$ & $38.8 \%$ \\
\hline Diamniadio & $6.0 \%$ & $19.9 \%$ & $0.6 \%$ & $58.4 \%$ & $3.6 \%$ & $3.6 \%$ & $6.6 \%$ & $92.2 \%$ & $17.5 \%$ & $68.7 \%$ & $31.9 \%$ \\
\hline Sebikotane & $3.8 \%$ & $17.0 \%$ & $0.0 \%$ & $55.5 \%$ & $2.2 \%$ & $0.0 \%$ & $0.0 \%$ & $44.0 \%$ & $21.4 \%$ & $79.7 \%$ & $27.5 \%$ \\
\hline Sebikotane & $5.7 \%$ & $17.3 \%$ & $0.0 \%$ & $49.7 \%$ & $26.0 \%$ & $0.0 \%$ & $16.8 \%$ & $75.7 \%$ & $25.4 \%$ & $65.9 \%$ & $41.6 \%$ \\
\hline Bambylor & $6.8 \%$ & $0.0 \%$ & $0.0 \%$ & $45.8 \%$ & $0.0 \%$ & $0.0 \%$ & $0.0 \%$ & $49.2 \%$ & $32.2 \%$ & $42.4 \%$ & $16.9 \%$ \\
\hline Sangalkam & $3.4 \%$ & $0.0 \%$ & $0.0 \%$ & $56.7 \%$ & $1.7 \%$ & $0.0 \%$ & $0.0 \%$ & $36.7 \%$ & $0.0 \%$ & $66.7 \%$ & $3.3 \%$ \\
\hline Sangalkam & $1.3 \%$ & $0.0 \%$ & $1.3 \%$ & $43.0 \%$ & $17.7 \%$ & $0.0 \%$ & $0.0 \%$ & $31.6 \%$ & $0.0 \%$ & $34.2 \%$ & $1.3 \%$ \\
\hline Peulh Niagha & $1.5 \%$ & $0.0 \%$ & $1.5 \%$ & $54.5 \%$ & $18.2 \%$ & $18.2 \%$ & $0.0 \%$ & $77.3 \%$ & $10.6 \%$ & $37.9 \%$ & $12.1 \%$ \\
\hline Peulh Niagha & $7.5 \%$ & $0.0 \%$ & $0.0 \%$ & $50.7 \%$ & $0.0 \%$ & $0.0 \%$ & $0.0 \%$ & $80.6 \%$ & $34.3 \%$ & $58.2 \%$ & $25.4 \%$ \\
\hline Jaxaay & $2.1 \%$ & $0.0 \%$ & $0.0 \%$ & $58.5 \%$ & $11.7 \%$ & $7.4 \%$ & $0.0 \%$ & $55.3 \%$ & $0.0 \%$ & $74.5 \%$ & $2.1 \%$ \\
\hline Jaxaay & $7.0 \%$ & $0.0 \%$ & $0.0 \%$ & $20.9 \%$ & $0.0 \%$ & $0.0 \%$ & $0.0 \%$ & $0.0 \%$ & $0.0 \%$ & $23.3 \%$ & $2.3 \%$ \\
\hline Jaxaay & $0.0 \%$ & $0.0 \%$ & $0.0 \%$ & $42.3 \%$ & $21.1 \%$ & $0.0 \%$ & $0.0 \%$ & $59.2 \%$ & $0.0 \%$ & $76.1 \%$ & $9.9 \%$ \\
\hline Yene & $3.8 \%$ & $0.0 \%$ & $0.0 \%$ & $56.2 \%$ & $0.0 \%$ & $0.0 \%$ & $0.0 \%$ & $85.0 \%$ & $0.0 \%$ & $40.0 \%$ & $3.8 \%$ \\
\hline Yene & $6.2 \%$ & $0.0 \%$ & $1.0 \%$ & $47.9 \%$ & $0.0 \%$ & $18.8 \%$ & $0.0 \%$ & $45.8 \%$ & $0.0 \%$ & $53.1 \%$ & $4.2 \%$ \\
\hline Rufisque & $3.2 \%$ & $15.8 \%$ & $0.4 \%$ & $48.6 \%$ & $7.4 \%$ & $1.6 \%$ & $4.3 \%$ & $42.9 \%$ & $10.1 \%$ & $61.7 \%$ & $23.2 \%$ \\
\hline
\end{tabular}

Calculation of authors. 